\title{
Tripleurospermum disciforme (C.A.Mey.) Sch.Bip., Tanacetum parthenium (L.) Sch.Bip, and Achillea biebersteinii Afan.: efficiency, chemical profile, and biological properties of essential oil
}

\author{
Mansureh Ghavam*
}

\begin{abstract}
Background: Tripleurospermum disciforme (C.A.Mey.) Sch.Bip., Tanacetum parthenium (L.) Sch.Bip., and Achillea biebersteinii Afan. are the most important species of the Asteraceae family that are used in traditional medicine as antiseptics, analgesics, and anti-ulcers. This study aimed to evaluate and compare the yield, chemical profile, and antibacterial and antifungal properties of the essential oils of these three species for the first time. For this purpose, plant materials were collected in June 2019 from Javinan region (Kashan, Iran).

Results: Based on the ANOVA results the species had a significant effect on yield, chemical composition, and diameter of the inhibition zone of some microorganisms $(P \leq 0.01)$. The highest yield belonged to $T$. disciforme essential oil ( 1.433\%). Analysis of essential oil compounds showed that in T. disciforme, anisole, $p$-1-cyclohexen-1-yl- (55.95\%), modephene (10.00\%), and cis- $\beta$-farnesene (11.94\%), in T. parthenium, camphor (43.43\%), camphene (9.40\%), and bornyl acetate (6.76\%), and in A. biebersteinii linalool (34.49\%), p-cymene (15.31\%), and a-terpineol (7.43\%) were the main and predominant compounds. The highest inhibition zone diameter by the essential oil of T. parthenium and A. biebersteinii against Aspergillus brasiliensis $(\sim 13 \mathrm{~mm})$ was observed. The strongest inhibitory and lethal activity was related to T. disciforme essential oil against Klebsiella pneumoniae, Shigella dysenteriae, Escherichia coli ( $8.50 \mathrm{~mm})$, and Candida albicans ( $\mathrm{MIC}$ and $\mathrm{MBC}=62.5 \mu \mathrm{g} / \mathrm{mL}$ ), which were equivalent to rifampin and twice as potent as nystatin, respectively.
\end{abstract}

Conclusions: Therefore, the essential oil of the studied species of Asteraceae may be a promising and potential strategy for controlling some microorganisms and a possible natural alternative to some antibiotics.

Keywords: Asteraceae, Yield, Essential oil compounds, Antimicrobial properties, T. disciforme

\section{Introduction}

Despite major medical breakthroughs over the past three decades, infectious diseases are still one of the leading causes of death in the world [1]. The discovery of antibiotics increases human health and longevity. However,

${ }^{*}$ Correspondence: mghavam@kashanu.ac.ir

Department of Range and Watershed Management, Faculty of Natural Resources and Earth Sciences, University of Kashan, Kashan, Iran increasing antibiotic resistance decreases the antibacterial activity of antibiotics [2]. Improper, excessive, and haphazard use of antibiotics to treat infectious diseases is one of the main reasons for the emergence of resistant microorganisms [3]. The global problem of antimicrobial resistance is of particular importance in developing countries, where bacterial and fungal infectious diseases are highly prevalent and cost constraints prevent the widespread use of newer and more expensive agents [4]. 
These infections are caused by several bacterial strains, such as Staphylococcus aureus, Staphylococcus epidermidis, Escherichia coli, and Pseudomonas aeruginosa [5]. Even after treatment, Candida strains cause high mortality, ranging from 40 to $60 \%$ [6]

Antimicrobial compounds of medicinal plants are one of the valuable resources in medicine and therefore, despite the spread of infectious diseases, identifying more of these plants and purifying their effective compounds can be useful in treating diseases [7, 8]. Essential oils have bioactivities including antimicrobial, antioxidant, anti-diabetic, and anti-cancer activities [9]. Their reputation as disinfectants stems from their use in traditional medicine around the world [10]. Essential oils with antibacterial activity can be a promising factor for this purpose. These compounds often affect the cell wall of microorganisms and due to their hydrophobic and oily nature, they penetrate the membrane structure [11]. Consequently, ions are released, resulting in changes in cell osmotic pressure and, finally, the death of microorganisms [12].

Asteraceae is the largest plant genus [13], and has been studied extensively due to many different genera and species, its global distribution, and the fact that it is endowed with many beneficial plants [14]. Previous studies on the antimicrobial properties of Asteraceae plants show their moderate-to-strong antimicrobial activity $[15,16]$.

Tripleurospermum disciforme (C.A.Mey.) Sch.Bip. is known as the "Plain Chamomile" of the Asteraceae family [17]. This plant has been cultivated in many parts of Iran and has been used in Iranian herbal medicine as a sedative and anti-inflammatory, and for relaxation, muscle pain, fatigue, and also in stress therapy [18]. In Iran, it has had many traditional and folk uses [19], but there were few reports of its antimicrobial effects [20]. According to recent studies, the essential oil of this species has anti-inflammatory [21-23], antispasmodic and antiseptic [17, 24], antifungal [25, 26], antibacterial [20, 27], and antioxidant effects $[28,29]$. So far, little research has been done on the chemical composition of $T$. disciforme essential oil. The main constituents of this essential oil are $p$-methoxy- $\beta$-cyclopropylstyrene, (E)- $\beta$-farnesene, $\beta$-sesquiphellandrene, and cis-calamenene [27, 29-34].

Tanacetum parthenium (L.) Sch.Bip. is a plant with a long history of use in traditional medicine [35]. All parts of the plant have a foul odor, especially after rubbing [36]. It is popularly known as "Feverfew" [37]. It is a well-known drug for treating a variety of ailments, including osteoarthritis, fever, dizziness, migraine, menstrual disorders, stomach pain, toothache, insect bites, and psoriasis [38]. According to recent studies, the essential oil of this plant has anti-inflammatory [39, 40], anticancer [41], antibacterial [15, 42-45], antifungal [46, 47], antiviral [48], and insecticidal effects [49]. The biological activity of this plant's essential oil is due to terpenoid components and the content of phenolic compounds including phenolic acids and flavonoids [40, 49]. The essential oils of Tanacetum species contain mainly sesquiterpenoids and flavonoids, while other terpenoids and phenolic compounds are rarely found in these plants [50]. In most cases, camphor and chrysanthenyl acetate are the main components in T. parthenium essential oil along with various secondary components [51-53]. While camphene, $p$-cymene, and (E)-Chrysanthenole were found in other studies in addition to previous superiority [15, $54,55]$. Some studies have shown that there are large amounts of sesquiterpene, lactone, parthenolide, and flavonoids in this plant, indicating its strong antibacterial activity [40, 55-57].

Due to the synthesis of significant amounts of secondary metabolites, especially essential oils, Achilles is one of the most important and valuable medicinal plants in the world and has wide applications in the pharmaceutical, cosmetic, and health industries of plant essential oils [58]. Achillea biebersteinii Afan. is one of the medicinal species of Achillea that has been used as an anti-flatulence and carminative medicine in Jordanian traditional medicine for a long time, while in Turkey it is used as a medicine to relieve abdominal pain and heal wounds [59-62]. Various biological activities such as antifungal [63, 64]), antibacterial [64], antioxidant [64-67] and insecticidal effects $[68,69]$ have been found in the essential oil of $A$. biebersteinii. According to previous studies, the main components of $A$. biebersteinii essential oil are oxygen monoterpenes. In this plant, piperitone, camphor, borneol, 8,1-cinnamol, para-cement, and ascaridole have been identified as the main constituents of essential oil $[62,64,68-74]$.

A review of studies shows that there are few reports of antimicrobial activity in the essential oils of these three species from some regions of Iran and the world against some microorganisms. On the other hand, so far no comprehensive and simultaneous study has been done on these species using different strains of microorganisms. Therefore, this research aimed to study and compare the chemical composition and antimicrobial activity of the essential oils of these three species against 11 strains.

\section{Materials and methods}

\section{Plant species collection and identification}

In order to sample the plants under study during their full flowering time, flowering branches of A. bieberstei$n i i$ and flowers of $T$. disciforme and T. parthenium were randomly collected from three points and different rootstocks (100 rootstocks per region) in Javinan region, located in Kashan, Iran (longitude: 51 26 $48^{\prime \prime}$ E; latitude: 
$33^{\circ} 41^{\prime} 22^{\prime \prime} \mathrm{N}$ ) in June 2019. After harvesting, the samples were transferred to the laboratory. Also, a complete plant sample of the species was collected and after identification in the herbarium of the Faculty of Natural Resources and Earth Sciences, University of Kashan, Kashan, was coded and stored. The plant was identified by Mansureh Ghavam and recorded with Code number 1410, 1411, and 1412.

\section{Extraction of essential oils by hydrodistillation (Clevenger apparatus)}

After complete drying, the samples were reduced to fine particles by a small electric mill. Then $100 \mathrm{~g}$ of each plant sample was weighed and its essential oil was extracted by distillation with water and using a Clevenger for $5 \mathrm{~h}$. The weight of essential oil collected after dehydration with sodium sulfate was accurately calculated and the yield of essential oil of three replications (points) was reported as the mean \pm standard deviation. The essential oils were then stored in dark bottles at $4{ }^{\circ} \mathrm{C}$ until use in the next step.

\section{Analysis of essential oil compounds Gas chromatography-mass spectrometry}

The composition of the obtained essential oil samples was determined by GC-MS. Chromatograph model 6890 coupled with Agilent mass spectrometer model N-5973 with capillary column HP-5MS with a static phase of $5 \%$ methylphenyl siloxane (length $30 \mathrm{~m}$, inner diameter $0.25 \mathrm{~mm}$, and thickness of static layer $0.25 \mu \mathrm{m}$ ) and ionization energy of $70 \mathrm{eV}$ were used to qualitatively identify the components. Temperature programming for analysis was first set at $60{ }^{\circ} \mathrm{C}$ and then increased by $3{ }^{\circ} \mathrm{C} / \mathrm{min}$ to reach $246{ }^{\circ} \mathrm{C}$. The temperature of the injector and the detector was $250{ }^{\circ} \mathrm{C}$, the volume of the injected sample was $1 \mu \mathrm{L}$ with a split mode of 1.50 , and helium gas with a flow rate of $1.5 \mathrm{~mL} / \mathrm{min}$.

\section{Identification of chemical constituents of essential oils}

Chemical components of essential oils were identified based on chromatogram analysis of each essential oil sample in relation to inhibition indices (RI), n-alkane (C8-C20) mixed standards, and mass spectral data of each peak using a computer library (spectral library Wiley-14 and NIST-14) and comparing the results with the results in the literature [75].

\section{Determination of antibacterial and antifungal activities Microbial strains and growth conditions}

Standard microbial strains include four Gram-positive bacteria Staphylococcus epidermidis (CIP 81.55), Staphylococcus aureus (ATCC 29737), Streptococcus pyogenes (ATCC 19615), and Bacillus subtilis (ATCC 6633), five
Gram-negative bacteria Klebsiella pneumonia (ATCC 10031), Escherichia coli (ATCC 10031), Pseudomonas aeruginosa (ATCC 27853), Salmonella paratyphi-A serotype (ATCC 5702), and Shigella dysenteriae (PTCC 1188) and three fungal strains of Aspergillus brasiliensis (ATCC 16404), Aspergillus niger (ATCC 9029), and Candida albicans (ATCC 16404), which were procured from the Iranian Scientific and Technological Research Organization (IROST). Bacterial strains were cultured in nutrient agar medium and fungi were cultured in Sabouraud dextrose agar medium, incubated overnight at $37^{\circ} \mathrm{C}$ and $30{ }^{\circ} \mathrm{C}$, respectively.

\section{Agar well diffusion (WD) assay}

Agar well diffusion method was performed according to the Institute of Clinical and Laboratory Standards [76]. Here, $100 \mu \mathrm{L}$ of microbial suspensions with turbidity equivalent to half McFarland were cultured under uniform conditions in the culture medium (Müller-Hinton agar medium for bacteria and sabouraud dextrose agar for fungi). The essential oil was dissolved in dimethyl sulfoxide (DMSO) to a concentration of $300 \mu \mathrm{g} / \mathrm{mL}$. Wells with a diameter of $6 \mathrm{~mm}$ and a thickness of $4 \mathrm{~mm}$ were made in culture media and $10 \mu \mathrm{L}$ of the essential oil was added to each well. Plates inoculated with bacterial strains were heated at $37^{\circ} \mathrm{C}$ for $24 \mathrm{~h}$ and those inoculated with fungi and yeast strains at $30{ }^{\circ} \mathrm{C}$ for 72 and $48 \mathrm{~h}$, respectively. Inhibition zone diameter was measured using an antibiogram ruler (in millimeters). The antibiotics gentamicin $(10 \mu \mathrm{g} / \mathrm{disc})$ and rifampin $(5 \mu \mathrm{g} /$ disc $)$ for bacteria and nystatin $(100,000 \mathrm{unit} / \mathrm{mL})$ for fungi were used as standard drugs for positive control under the same conditions. Dimethyl-sulfoxide was used as negative control. For each essential oil, the experiment was repeated three times and the inhibition zone diameter was reported in terms of mean \pm standard deviation.

\section{Minimal inhibitory concentration (MIC) and minimal bactericidal/fungicidal concentration (MBC/MFC) assay}

To determine the minimum inhibitory concentration (MIC) of bacterial and yeast strains, a 96-well microtiter plate sterile and broth microdilution method were used according to the CLSI agenda [76]. For fungal strains, the agar dilution assay method was used according to the agenda of Gul et al. [77]. At first, various dilutions of essential oils were prepared. In this way, a certain amount of essential oil sample was weighed and a suitable ratio of culture medium and solvent of dimethyl sulfoxide was used to prepare the initial stock, so that the initial concentration of $4000 \mu \mathrm{g} / \mathrm{mL}$ was selected. Then, 2000, $500,250,125,62.5,31.25$, and $15.63 \mu \mathrm{g} / \mathrm{mL}$ concentrations were prepared from the initial concentration. Each microplate well received $200 \mu \mathrm{L}$ of a solution containing 
$95 \mu \mathrm{L}$ brain heart infusion (BHI) broth for bacteria, Sabouraud dextrose broth for yeast, and Sabouraud dextrose agar broth for fungi, $5 \mu \mathrm{L}$ bacterial suspension with 0.5 McFarland dilution, and $100 \mu \mathrm{L}$ of one of the different essential oil concentrations. Plates with bacterial strains were inoculated at $37{ }^{\circ} \mathrm{C}$ for $24 \mathrm{~h}$ and those with yeast and fungi at $30{ }^{\circ} \mathrm{C}$ for 48 and $72 \mathrm{~h}$. The resulting color change in each of the microplate wells was determined through MIC. In wells related to the negative control, the culture medium was used instead of essential oil. For positive control, gentamicin and rifampin antibiotic powder for bacteria and nystatin antibiotic powder for yeast and fungi were used instead of essential oil. The experiment was repeated three times for each essential oil sample and reported as MIC. To determine the minimum bactericidal/fungicidal concentration (MBC/MFC), $5 \mu \mathrm{L}$ of each microplate well with no growth (clear well) was inoculated into nutrient agar/Sabouraud dextrose agar medium and incubated at $37{ }^{\circ} \mathrm{C}$ for $24 \mathrm{~h}$ for bacterial strains, and for $48 \mathrm{~h}$ and $72 \mathrm{~h}$ at $30^{\circ} \mathrm{C}$ for fungal strains.

\section{Statistical analysis}

The statistical analysis was performed using SPSS 22 . Data normality was checked using the KolmogorovSmirnov test. After ensuring the normality of the data, the variance of the data (essential oil and antimicrobial activity) was analyzed using one-way analysis of variance (ANOVA) and univariate. All the data were analyzed in triplicates and expressed as mean \pm SD with Duncan test at $\alpha=0.01$.

\section{Results}

\section{Essential oil yield}

Based on the ANOVA results, the essential oil yield of the three species was significantly different (Table 1). The highest yield belonged to T. disciforme essential oil $(1.433+0.006 \%)$ with saffron yellow color. A. biebersteinii essential oil with pale yellow color and a yield of $0.717+0.006 \%$ was ranked second in terms of yield. The essential oil of T. parthenium was blue and its yield was $0.650+0.010 \%$, which was the lowest yield.

\section{GC-MS analysis of essential oils}

Based on the results of essential oil analysis by GC-MS, 109 different compounds (98.78-99.55\%) were identified in the studied species (Table 2) whose profiles are shown in Figs. 1, 2 and 3. Oxygenated monoterpenes were the largest group of compounds in A. biebersteinii (51.76\%). In T. parthenium, oxygenated monoterpenes with $47.21 \%$ contained the highest percentage of compounds. However, in T. disciforme, nonterpenoids with $61.95 \%$ were the most common compounds.
Based on the findings, only the composition of Caryophyllene was observed in the essential oils of all three species. ANOVA results showed that there was a significant difference between the means of combination of different species $(P \leq 0.01) \quad$ (Tables 1 and 2$)$. The amount of this compound was very small and its highest amount was observed in the essential oil of T. disciforme (1.66\%). Anisole, p-1-cyclohexen-1-yl- (55.95\%), and modephene $(10.00 \%)$ were the most important predominant compounds in T. disciforme essential oil. Meanwhile, cis- $\beta$-farnesene $(11.94 \%)$ was the second predominant component of $T$. disciforme essential oil.

$\beta$-Sesquiphellandrene with $6.58 \%$ was another major compound in T. disciforme consistent with the findings of Cavar Zeljkovic et al. [29] (9.29\%), Chehregani et al. [27] (17.85\%), and Javidnia et al. [30] (4.15\%). However, Nazar Alipoor and Sefidkon [78] reported a small amount $(0.22 \%)$, which contradicts the present results.

Camphor with $43.43 \%$ was the predominant composition of T. parthenium essential oil, which was also observed in $T$. disciforme essential oil (0.15\%). The second dominant compound in T. parthenium essential oil was camphene $(9.40 \%)$. Bornyl acetate with $6.76 \%$ was another major component of T. parthenium essential oil.

In A. biebersteinii essential oil, linalool (34.49\%), p-cymene (15.31\%), $\alpha$-terpineol (7.43\%), terpinen-4-ol (5.04\%), and linalool acetate $(4.35 \%)$ were the predominant compounds.

\section{Analysis of antimicrobial properties of essential oils}

ANOVA results showed that the species had a significant effect on the inhibition zone diameter of essential oils of different species due to some microorganisms $(P \leq 0.01)$ (Table 3$)$. The evaluation of the antimicrobial activity of essential oils in the studied species by agar well diffusion method against different strains is shown in Table 4. The highest inhibition zone diameter by the essential oil of T. parthenium and A. biebersteinii against Aspergillus brasiliensis $(\sim 13 \mathrm{~mm})$ was observed here, which showed relatively good antifungal activity in comparison with the antibiotic nystatin $(\sim 30 \mathrm{~mm})$. T. disciforme essential oil has also affected this fungus with less power $(\sim 12 \mathrm{~mm})$. Similarly, the inhibition zone diameter of essential oil of T. parthenium and A. biebersteinii against Gram-positive B. subtilis ( $13 \mathrm{~mm}$ ) had relatively good activity compared to rifampin $(\sim 19 \mathrm{~mm})$ and relatively good activity compared to gentamicin $(\sim 30 \mathrm{~mm})$. The potency of this activity was reduced in the essential oil of $T$. disciforme $(\sim 9 \mathrm{~mm})$. The findings also indicated that the MIC and MFC values of the essential oils of all three species against $A$. brasiliensis were $2000 \mu \mathrm{g} / \mathrm{mL}$, which performed poorly compared to rifampin $(31.2 \mu \mathrm{g} /$ $\mathrm{mL}$ ) (Tables 5 and 6). On the other hand, T. disciforme 
Table 1 ANOVA of the effect of species on yield and caryophyllene of essential oils of Tripleurospermum disciforme (C.A.Mey.) Sch.Bip., Tanacetum parthenium (L.) Sch.Bip. and Achillea biebersteinii Afan

\begin{tabular}{lrll}
\hline $\begin{array}{l}\text { Source of } \\
\text { variation }\end{array}$ & Df & MS & $\begin{array}{l}\text { Yield of essential Caryophyllene } \\
\text { oil }\end{array}$ \\
\hline Species & 2 & $0.566^{* *}$ & $1.743^{* *}$ \\
Error & 10 & 0.000056 & 0.000015 \\
\hline
\end{tabular}

** $1 \%$ level of probability is significant

essential oil with MIC value equal to $125 \mu \mathrm{g} / \mathrm{mL}$ against B. subtilis had better inhibitory power compared to the other two essential oils $(2000 \mu \mathrm{g} / \mathrm{mL})$.

Another notable activity of $T$. disciforme essential oil is establishing the diameter of the inhibition zone against Gram-negative $K$. pneumoniae $(\sim 8.50 \mathrm{~mm})$, which has a strong activity equal to rifampin $(\sim 8 \mathrm{~mm})$ and has a relatively good activity compared to gentamicin $(\sim 17 \mathrm{~mm})$. The findings also indicate that the $\mathrm{MIC}$ and $\mathrm{MBC}$ values of this essential oil against this bacterium were 125 and $250 \mu \mathrm{g} / \mathrm{mL}$, respectively, which are relatively significant concentrations compared to rifampin $(15.36 \mu \mathrm{g} / \mathrm{mL})$ and gentamicin $(3.90 \mu \mathrm{g} /$ $\mathrm{mL})$. Similarly, this essential oil fights against Gramnegative bacteria Sh. dysenteriae and E. coli $(\sim 8 \mathrm{~mm})$ with a strong activity compared to rifampin ( $\sim 9$ and $\sim 11 \mathrm{~mm}$ ) and relatively good activity compared to gentamicin $(\sim 17$ and $\sim 20 \mathrm{~mm})$. Although this essential oil's inhibitory effect $(\mathrm{MIC}=125 \mu \mathrm{g} / \mathrm{mL})$ and lethality $(\mathrm{MBC}=250 \mu \mathrm{g} / \mathrm{mL})$ against Sh. dysenteriae and E. coli were relatively strong, it had poorer performance compared to control antibiotics.

The strongest inhibitory and lethal activity of $T$. disciforme essential oil was against Candida albicans (MIC and $\mathrm{MBC}<62.50 \mu \mathrm{g} / \mathrm{mL}$ ), which is very significant (twice as strong) compared to nystatin $(125 \mu \mathrm{g} / \mathrm{mL})$. The effect of this essential oil in creating the inhibition zone diameter $(\sim 10 \mathrm{~mm})$ was less potent than that of nystatin $(\sim 33 \mathrm{~mm})$ against $C$. albicans.

Although T. disciforme essential oil did not affect the inhibition zone diameter against other bacterial strains, with different concentrations, it affected their inhibition and lethality. One of the significant inhibitory and lethal activities of false $T$. disciforme essential oil was against Gram-negative bacteria $P$. aeruginosa (MIC and $\mathrm{MBC}>62.50 \mu \mathrm{g} / \mathrm{mL}$ ), which has a strong activity in comparison with rifampin $(31.25 \mu \mathrm{g} / \mathrm{mL})$ and relatively good activity in comparison with gentamicin $(7.81 \mu \mathrm{g} /$ $\mathrm{mL})$, but this inhibitory power $(2000 \mu \mathrm{g} / \mathrm{mL})$ was severely reduced in the other two essential oils.

T. parthenium essential oil had a relatively good activity compared to rifampin and gentamicin $(\sim 21 \mathrm{~mm}$ and $\sim 27 \mathrm{~mm}$ ) by creating a growth inhibition zone diameter of about $10 \mathrm{~mm}$ against Gram-positive $S$. aureus bacteria, which is consistent with the antibacterial activity against this bacterium in Hamedan $(\sim 28 \mathrm{~mm})$. However, the inhibitory and lethal power of the essential oil against this bacterium $(\mathrm{MIC}=2000 \mu \mathrm{g} / \mathrm{mL}$ and $\mathrm{MBC}=4000 \mu \mathrm{g} / \mathrm{mL}$ ) was very weak.

\section{Discussion}

The effect of species on essential oil yield was significant $(P \leq 0.01)$ (Table 1). Similar results were obtained by Golkar et al. [79] for species of the genus Thymus and Zataria, Silva et al. [80] for species of the Myrtaceae family, and Ngahang Kamte et al. [81] for species of the Apiaceae family. Researchers have shown that the essential oil yield of species varies depending on the species, solvent, and extraction method and is sometimes affected by ecological stresses in the region [82].

The highest yield belonged to $T$. disciforme essential oil $(1.433+0.006 \%)$ with saffron yellow color which was higher than the study by Nazar Alipoor and Sefidkon [78] in Taleghan (0.43\%), Javidnia et al. [30] in Shiraz (0.16\%), Chehregani et al. [27] in Hamedan (0.92\%), and Özturk et al. [34] in Turkey (0.04\%). However, in the study of Alizadeh et al. [83], the highest yield was recorded in Ardabil (13.3\%), which is higher than the present study. The difference in essential oil yield was consistent with the theory of Golparvar and Ghasemi Pirbalouti [84], reporting that essential oil is a quantitative and complex trait influenced by a variety of factors including population genetics, crop density and arrangement, irrigation schedule, fertilization, history of planting, temperature, and light. When the plant can make the most of these factors, it will also produce the most quantitative and qualitative yield. The essential oil of $T$. parthenium was blue and its yield was $0.650+0.010 \%$, which was consistent with the results of Shakeri et al. [85] in Irene (0.7\%) and Polatoglu et al. [15] in Turkey $(0.7 \%)$. However, it was not consistent with Mohsenzadeh et al. [43] in Iran (1.02\%), Shafaghat et al. [86] in Iran (0.8\%), Maxia et al. [46] in Italy (0.4\%), and Akpulat et al. [53] in Turkey (0.43\%). The highest yield of essential oil of this species was recorded in Masuleh hills of Iran with a value of 3.5\% [51].

The lowest number of compounds belonged to the essential oil of $T$. disciforme (26 compounds), which was significantly different from the number of compounds in T. parthenium and A. biebersteinii species (44 and 55 compounds). Similarly, Chehregani et al. [27] recorded 21 compounds in T. disciforme. According to chemical studies, the main components of $A$. biebersteinii essential oil are oxygenated monoterpenes [67]. On the contrary, in the studies by Özturk et al. [34] and Javidnia et al. [30], sesquiterpene hydrocarbons were the major constituents 
of the essential oil of this plant. Changes in the chemical composition of essential oils are due to physiological changes, environmental conditions, geographical changes, genetic factors, evolution, as well as the amount of plant material [87].

The amount of Caryophyllene was very small and its highest amount was observed in the essential oil of $T$. disciforme (1.66\%). Anisole, $p$-1-cyclohexen-1-yl- and modephene have not been reported before in T. disciforme, and are most likely due to chemotypic differences induced by environmental conditions and climate of the studied habitats [88-91], indicating the unique characteristics of this plant in this area. Meanwhile, cis- $\beta$-Farnesene recorded by Nazar Alipoor and Sefidkon [78] with $12.54 \%$ and Özturk et al. [34] with $18.2 \%$ in T. disciforme essential oil. It has four geometric isomers as reported by Javidnia et al. [30], with the isomer (E)- $\beta$-Farnesene as the dominant compound in this plant (15.6\%). Farnesene is a component of many aromatic essential oils. It is a fragrant perfume that has many applications and is a very useful substance in the production of quality perfumes [78].

Similarly, in previous studies, camphor was $56.9 \%$ in Sivas, Turkey [53], 48.90\% in Tehran [44], 60.8\% in Savat, Turkey [15], 45.01\% in Hamedan [45], 52.86\% in Shahrekord [85], 45.5\% in Khalkhal-Asalem road, Ardabil province, [86], and 43.97\% in Masuleh hills [51], recording the dominant composition of T. parthenium essential oil. Camphor has many applications in traditional and modern medicine. It is also important as an antiseptic compound with very effective antibiotic effects [92].

Also camphene reported by Shakeri et al. [85] at 9.1\%, Polatoglu et al. [15] at 6.8\%, Akpulat et al. [53] at 12.7\%, and Shafaghat et al. [86] at $6.95 \%$. This was, however, inconsistent with Rezaei et al. [51]. Some of camphene medicinal effects are acting as a sedative, antidepressant, anti-diarrheal, analgesic and it has also shown antiabortion effects in pregnant mice. Bornyl acetate has been reported as the third dominant compound in various studies with $8.63 \%$ [85], 2.9\% [15], and 4.6\% [53]. This is inconsistent with the results of Rezaei et al. [51], Mohsenzadeh et al. [43], and Saharkhiz et al. [44]. Bornyl acetate is used as a food additive and for flavoring and fragrance [93].

Linalool in A. biebersteinii essential oil is mainly either not reported or identified in very small amounts of $1.4 \%$ [72], 0.45\% [64], 2.3\% [69], and 0.2\% [67], which is inconsistent with the present results. Changes in the chemical properties of essential oils in different regions related to factors affecting the chemical composition of essential oils (i.e., genetic, climatic, seasonal, and geographical conditions as well as changes in secondary metabolism, the effect of planting time, growth stage, and biological stresses such as drought or salinity). In addition, extraction techniques and storage conditions can also affect the composition of essential oils [94].

Linalool has important therapeutic effects, especially antimicrobial activity [89-91, 95]. Linalool is found only in large quantities in coriander seeds [96] and its presence in significant amounts in the studied A. biebersteinii essential oil can be a reason that this species is a chemotype in this region, rich in valuable chemical compounds. Moreover, $p$-cymene has been reported as one of the predominant essential oil compounds of this plant in other studies with varying amounts, including $20.8 \%$ [97], 16.9-34.8\% [67], 19.2\% [74], and 4.6\% [69], which is consistent with the present findings. Antibacterial effects have also been observed in this compound [98]. The compounds $\alpha$-terpineol and terpinen-4-ol in this essential oil were either mostly not present or in small amounts in previous studies, for instance, $3.2 \%$ and $2.7 \%$ [73], 2.2\% and $0.9 \%$ [67], and $1.2 \%$ and $2.7 \%$ [74], which does not correspond to the present study. Linalool acetate has not been reported in any of the previous studies on this plant. These differences can be due to the effect of different ecological, additive, and climatic factors on the composition of essential oils of different populations of the same species that are distributed and grown in different geographical areas [88]. Linalool acetate and Linalool are the main components of lavender essential oil. This suggests that the studied $A$. biebersteinii, like lavender, could be a potential source for extracting these compounds.

The effect of plant essential oils on Gram-positive bacteria was greater than their effect on Gram-negative bacteria [99]. Caryophyllene was the only common compound in all three essential oils, the largest amount of this compound belonged to T. disciforme, which can be one of the contributing factors. Similarly, Shafaghat et al. [86] and Polatoglu et al. [15] reported the relatively good effect of $T$. parthenium essential oil on B. subtilis $(17.9 \pm 0.2 \mathrm{~mm}$ and $125 \mu \mathrm{g} / \mathrm{mL})$, which is consistent with the present findings. Furthermore, in Baris et al. [64], no inhibition zone diameter from $A$. biebersteinii essential oil against $B$. subtilis was observed, which contradicts the present results. It should be noted that the antifungal activity against $A$. brasiliensis by the studied essential oils has not been recorded in any region so far and this is the present study is the first to identify this antifungal activity. The antimicrobial activity of different essential oils depends on their chemical profile [89-91, 100]. It seems that the similarity of the antimicrobial activity of A. biebersteinii and T. parthenium essential oils can be due to the similarity of their chemical profile, especially in terms of monoterpenes such as $\alpha$-pinene, camphene, sabinene, $\delta$-carene, $p$-cymene, and $\gamma$-terpinene. Terpenes are a group of organic materials found abundantly in nature [101]. Terpenes with high hydrophobic properties 
Table 2 Compounds identified by GC-MS of the essential oils of Tripleurospermum disciforme (C.A.Mey.) Sch.Bip., Tanacetum parthenium (L.) Sch.Bip. and Achillea biebersteinii Afan

\begin{tabular}{|c|c|c|c|c|c|c|c|}
\hline No. & Component & RI Exp & RI Lit & $\begin{array}{l}\text { Tripleurospermum } \\
\text { disciforme } \\
\text { (C.A.Mey.) Sch.Bip }\end{array}$ & $\begin{array}{l}\text { Tanacetum } \\
\text { parthenium (L.) } \\
\text { Sch.Bip }\end{array}$ & $\begin{array}{l}\text { Achillea } \\
\text { biebersteinii } \\
\text { Afan }\end{array}$ & $\begin{array}{l}\text { Molecular } \\
\text { formula }\end{array}$ \\
\hline 1 & $\begin{array}{l}\text { 1,3-Cyclopentadiene, } \\
\text { 5-(1,1-dimethylethyl)- }\end{array}$ & 800.000 & 788 & & $1.72 \pm 0.00^{\mathrm{a}}$ & & $\mathrm{C}_{9} \mathrm{H}_{14}$ \\
\hline 2 & 1-Butanol, 2-methyl- & 800.200 & 762 & & & $0.13 \pm 0.02^{\mathrm{a}}$ & $\mathrm{C}_{5} \mathrm{H}_{12} \mathrm{O}$ \\
\hline 3 & $\begin{array}{l}\text { Isobutyric acid, isobutyl } \\
\text { ester }\end{array}$ & 855.172 & 908 & & & $0.07 \pm 0.01^{\mathrm{a}}$ & $\mathrm{C}_{8} \mathrm{H}_{16} \mathrm{O}_{2}$ \\
\hline 4 & Tricyclene & 870.443 & 921 & & $0.57 \pm 0.02^{\mathrm{a}}$ & & $\mathrm{C}_{10} \mathrm{H}_{16}$ \\
\hline 5 & a-Thujene & 871.921 & 924 & & & $0.40 \pm 0.00^{\mathrm{a}}$ & $\mathrm{C}_{10} \mathrm{H}_{16}$ \\
\hline 6 & a-Pinene & 880.788 & 932 & & $0.48 \pm 0.02^{b}$ & $1.03 \pm 0.02^{\mathrm{a}}$ & $\mathrm{C}_{10} \mathrm{H}_{16}$ \\
\hline 7 & Camphene & 902.317 & 953 & & $9.40 \pm 0.04^{a}$ & $0.19 \pm 0.00^{b}$ & $\mathrm{C}_{10} \mathrm{H}_{16}$ \\
\hline 8 & Sabinene & 917.880 & 969 & & $0.12 \pm 0.01^{b}$ & $2.17 \pm 0.01^{\mathrm{a}}$ & $\mathrm{C}_{10} \mathrm{H}_{16}$ \\
\hline 9 & $\beta$-Pinene & 921.192 & 974 & & $0.33 \pm 0.00^{\mathrm{a}}$ & & $\mathrm{C}_{10} \mathrm{H}_{16}$ \\
\hline 10 & $\beta$-Myrcene & 932.119 & 988 & & & $1.31 \pm 0.00^{\mathrm{a}}$ & $\mathrm{C}_{10} \mathrm{H}_{16}$ \\
\hline 11 & Furan, 2-pentyl- & 932.119 & 996 & $0.20 \pm 0.00^{\mathrm{a}}$ & $0.19 \pm 0.01^{\mathrm{a}}$ & & $\mathrm{C}_{9} \mathrm{H}_{14} \mathrm{O}$ \\
\hline 12 & a-Phellandrene & 944.701 & 1002 & & & $1.39 \pm 0.01^{\mathrm{a}}$ & $\mathrm{C}_{10} \mathrm{H}_{16}$ \\
\hline 13 & $\delta$-Carene & 952.980 & 1008 & & $0.22 \pm 0.02^{b}$ & $1.32 \pm 0.01^{\mathrm{a}}$ & $\mathrm{C}_{10} \mathrm{H}_{16}$ \\
\hline 14 & p-Cymene & 963.245 & 1020 & & $3.27 \pm 0.00^{b}$ & $15.31 \pm 0.03^{\mathrm{a}}$ & $\mathrm{C}_{10} \mathrm{H}_{14}$ \\
\hline 15 & $\beta$-Ocimene & 980.463 & 1032 & & & $0.96 \pm 0.01^{\mathrm{a}}$ & $\mathrm{C}_{10} \mathrm{H}_{16}$ \\
\hline 16 & -Terpinene & 990.066 & 1054 & & $1.36 \pm 0.01^{b}$ & $2.54 \pm 0.00^{\mathrm{a}}$ & $\mathrm{C}_{10} \mathrm{H}_{16}$ \\
\hline 17 & Filifolone & 1023.809 & 1082 & & $0.27 \pm 0.02^{\mathrm{a}}$ & & $\mathrm{C}_{10} \mathrm{H}_{14} \mathrm{O}$ \\
\hline 18 & a-Terpinolene & 1012.698 & 1086 & & & $1.15 \pm 0.00^{\mathrm{a}}$ & $\mathrm{C}_{10} \mathrm{H}_{16}$ \\
\hline 19 & Linalool oxide & 1005.820 & 1093 & & & $0.39 \pm 0.00^{\mathrm{a}}$ & $\mathrm{C}_{10} \mathrm{H}_{18} \mathrm{O}_{2}$ \\
\hline 20 & Linalool & 1049.735 & 1095 & & & $34.49 \pm 0.02^{\mathrm{a}}$ & $\mathrm{C}_{10} \mathrm{H}_{18} \mathrm{O}$ \\
\hline 21 & $\begin{array}{l}\text { 2H-Pyran-3(4H)-one, } \\
\text { 6-ethenyldihydro-2,2,6- } \\
\text { trimethyl- }\end{array}$ & 1026.984 & 1109 & & $0.99 \pm 0.05^{\mathrm{a}}$ & & $\mathrm{C}_{10} \mathrm{H}_{16} \mathrm{O}_{2}$ \\
\hline 22 & Chrysanthenone & 1041.798 & 1124 & & $0.47 \pm 0.01^{\mathrm{a}}$ & & $\mathrm{C}_{10} \mathrm{H}_{14} \mathrm{O}$ \\
\hline 23 & Camphor & 1056.084 & 1141 & $0.15 \pm 0.01^{b}$ & $43.43 \pm 0.03^{a}$ & & $\mathrm{C}_{10} \mathrm{H}_{16} \mathrm{O}$ \\
\hline 24 & (+)-Camphor & 1076.984 & 1142 & & $0.38 \pm 0.01^{\mathrm{a}}$ & & $\mathrm{C}_{10} \mathrm{H}_{16} \mathrm{O}$ \\
\hline 25 & Borneol & 1081.460 & 1165 & & $0.95 \pm 0.01^{\mathrm{a}}$ & & $\mathrm{C}_{10} \mathrm{H}_{18} \mathrm{O}$ \\
\hline 26 & Albene & 1061.111 & 1166 & $0.13 \pm 0.00^{\mathrm{a}}$ & & & $\mathrm{C}_{12} \mathrm{H}_{18}$ \\
\hline 27 & Lilac aldehyde D & 1062.169 & 1169 & & & $0.15 \pm 0.00^{\mathrm{a}}$ & $\mathrm{C}_{10} \mathrm{H}_{16} \mathrm{O}_{2}$ \\
\hline 28 & Nerol oxide & 1067.724 & 1154 & & & $0.83 \pm 0.00^{\mathrm{a}}$ & $\mathrm{C}_{10} \mathrm{H}_{16} \mathrm{O}$ \\
\hline 30 & $\beta$-Citronellene & 1078.190 & 1088 & & & $0.14 \pm 0.01^{\mathrm{a}}$ & $\mathrm{C}_{10} \mathrm{H}_{18}$ \\
\hline 31 & Biisobutenyl & 1079.894 & 1032 & & & $0.28 \pm 0.00^{\mathrm{a}}$ & $\mathrm{C}_{8} \mathrm{H}_{14}$ \\
\hline 32 & (-)-Terpinen-4-ol & 1086.243 & 1175 & & $1.38 \pm 0.04^{\mathrm{a}}$ & & $\mathrm{C}_{10} \mathrm{H}_{18} \mathrm{O}$ \\
\hline 33 & Terpinen-4-ol & 1093.650 & 1177 & & & $5.04 \pm 0.02^{\mathrm{a}}$ & $\mathrm{C}_{10} \mathrm{H}_{18} \mathrm{O}$ \\
\hline 34 & a-Terpineol & 1108.413 & 1186 & & & $7.43 \pm 0.01^{\mathrm{a}}$ & $\mathrm{C}_{10} \mathrm{H}_{18} \mathrm{O}$ \\
\hline 35 & Cyclofenchene & 1099.206 & 882 & & $0.45 \pm 0.03^{\mathrm{a}}$ & & $\mathrm{C}_{10} \mathrm{H}_{16}$ \\
\hline 36 & Sabinol & 1113.701 & 1137 & & $0.33 \pm 0.00^{\mathrm{a}}$ & & $\mathrm{C}_{10} \mathrm{H}_{16} \mathrm{O}$ \\
\hline 37 & Captan & 1113.461 & 1141 & & & $0.70 \pm 0.00^{\mathrm{a}}$ & $\mathrm{C}_{9} \mathrm{H}_{8} \mathrm{Cl}_{3} \mathrm{NO}_{2} \mathrm{~S}$ \\
\hline 38 & cis-Geraniol & 1125.240 & 1231 & & & $0.75 \pm 0.00^{\mathrm{a}}$ & $\mathrm{C}_{10} \mathrm{H}_{18} \mathrm{O}$ \\
\hline 39 & Linalool acetate & 1131.971 & 1253 & & & $4.35 \pm 0.02^{\mathrm{a}}$ & $\mathrm{C}_{12} \mathrm{H}_{20} \mathrm{O}_{2}$ \\
\hline 40 & Geraniol & 1141.346 & 1249 & & & $2.70 \pm 0.00^{\mathrm{a}}$ & $\mathrm{C}_{10} \mathrm{H}_{18} \mathrm{O}$ \\
\hline 41 & Bornyl acetate & 1149.759 & 1287 & & $6.76 \pm 0.03^{\mathrm{a}}$ & & $\mathrm{C}_{12} \mathrm{H}_{20} \mathrm{O}_{2}$ \\
\hline 42 & (-)-Bornyl acetate & 1151.201 & 1289 & & & $0.39 \pm 0.01^{\mathrm{a}}$ & $\mathrm{C}_{12} \mathrm{H}_{20} \mathrm{O}_{2}$ \\
\hline 43 & Silphiperfol-5-ene & 1172.355 & 1330 & $0.16 \pm 0.01^{\mathrm{a}}$ & & & $\mathrm{C}_{15} \mathrm{H}_{24}$ \\
\hline 44 & a-Guaiene & 1186.778 & 1437 & $0.90 \pm 0.00^{\mathrm{a}}$ & & & $\mathrm{C}_{15} \mathrm{H}_{24}$ \\
\hline
\end{tabular}


Table 2 (continued)

\begin{tabular}{|c|c|c|c|c|c|c|c|}
\hline No. & Component & RI Exp & RI Lit & $\begin{array}{l}\text { Tripleurospermum } \\
\text { disciforme } \\
\text { (C.A.Mey.) Sch.Bip }\end{array}$ & $\begin{array}{l}\text { Tanacetum } \\
\text { parthenium (L.) } \\
\text { Sch.Bip }\end{array}$ & $\begin{array}{l}\text { Achillea } \\
\text { biebersteinii } \\
\text { Afan }\end{array}$ & $\begin{array}{l}\text { Molecular } \\
\text { formula }\end{array}$ \\
\hline$\overline{45}$ & a-Terpineol acetate & 1191.586 & 1367 & & & $1.22 \pm 0.03^{\mathrm{a}}$ & $\mathrm{C}_{12} \mathrm{H}_{20} \mathrm{O}_{2}$ \\
\hline 46 & Nerol acetate & 1197.836 & 1365 & & & $1.05 \pm 0.00^{\mathrm{a}}$ & $\mathrm{C}_{12} \mathrm{H}_{20} \mathrm{O}_{2}$ \\
\hline 47 & Y-Patchoulene & 1199.519 & 1502 & & $0.15 \pm 0.00^{\mathrm{a}}$ & & $\mathrm{C}_{15} \mathrm{H}_{24}$ \\
\hline 48 & a-Cubebene & 1204.028 & 1381 & & $0.56 \pm 0.01^{\mathrm{a}}$ & & $\mathrm{C}_{15} \mathrm{H}_{24}$ \\
\hline 49 & Geraniol acetate & 1210.663 & 1386 & & & $2.15 \pm 0.02^{\mathrm{a}}$ & $\mathrm{C}_{12} \mathrm{H}_{20} \mathrm{O}_{2}$ \\
\hline 50 & Modephene & 1213.033 & 1392 & $10.00 \pm 0.01^{\mathrm{a}}$ & $0.37 \pm 0.02^{b}$ & & $\mathrm{C}_{15} \mathrm{H}_{24}$ \\
\hline 51 & cis-Jasmone & 1221.090 & 1396 & & & $1.35 \pm 0.01^{\mathrm{a}}$ & $\mathrm{C}_{11} \mathrm{H}_{16} \mathrm{O}$ \\
\hline 52 & Caryophyllene & 1233.886 & 1418 & $1.66 \pm 0.00^{\mathrm{a}}$ & $0.25 \pm 0.01^{c}$ & $0.46 \pm 0.02^{b}$ & $\mathrm{C}_{15} \mathrm{H}_{24}$ \\
\hline 53 & $\begin{array}{l}\text { Propanoic acid, 2-methyl-, } \\
\text { 1,7,7-trimethylbicy- } \\
\text { clo[2.2.1 hept-2-yl ester, } \\
\text { exo- }\end{array}$ & 1226.540 & 1419 & & $0.49 \pm 0.00^{\mathrm{a}}$ & & $\mathrm{C}_{14} \mathrm{H}_{24} \mathrm{O}_{2}$ \\
\hline 54 & Selina-5,11-diene & 1227.962 & 1447 & $0.79 \pm 0.01^{\mathrm{a}}$ & & & $\mathrm{C}_{15} \mathrm{H}_{24}$ \\
\hline 55 & trans- $\beta$-Farnesene & 1250.473 & 1461 & & & $0.10 \pm 0.00^{\mathrm{a}}$ & $\mathrm{C}_{15} \mathrm{H}_{24}$ \\
\hline 56 & cis- $\beta$-Farnesene & 1255.450 & 1454 & $11.94 \pm 0.01^{\mathrm{a}}$ & $1.29 \pm 0.03^{\mathrm{a}}$ & & $\mathrm{C}_{15} \mathrm{H}_{24}$ \\
\hline 57 & $\gamma$-Selinene & 1266.113 & 1492 & & & $0.16 \pm 0.02^{\mathrm{a}}$ & $\mathrm{C}_{15} \mathrm{H}_{24}$ \\
\hline 58 & Germacrene D & 1271.327 & 1484 & & $2.43 \pm 0.03^{\mathrm{a}}$ & $0.22 \pm 0.01^{b}$ & $\mathrm{C}_{15} \mathrm{H}_{24}$ \\
\hline 59 & Bornyl isovalerate & 1281.279 & 1512 & & $2.81 \pm 0.01^{\mathrm{a}}$ & & $\mathrm{C}_{15} \mathrm{H}_{26} \mathrm{O}_{2}$ \\
\hline 60 & a-Amorphene & 1271.563 & 1483 & $1.17 \pm 0.04^{\mathrm{a}}$ & & & $\mathrm{C}_{15} \mathrm{H}_{24}$ \\
\hline 61 & Aromandendrene & 1275.592 & 1439 & & & $0.05 \pm 0.00^{\mathrm{a}}$ & $\mathrm{C}_{15} \mathrm{H}_{24}$ \\
\hline 62 & $\beta$-Bisabolene & 1283.649 & 1506 & $0.70 \pm 0.01^{\mathrm{a}}$ & & & $\mathrm{C}_{15} \mathrm{H}_{24}$ \\
\hline 63 & $\beta$-Sesquiphellandrene & 1296.445 & 1525 & $6.58 \pm 0.02^{\mathrm{a}}$ & $0.64 \pm 0.00^{b}$ & & $\mathrm{C}_{15} \mathrm{H}_{24}$ \\
\hline 64 & $\begin{array}{l}\text { 3H-Pyrazol-3-one, 2,4-dihy- } \\
\text { dro-2-methyl-5-phenyl- }\end{array}$ & 1304.600 & 1540 & & & $0.17 \pm 0.00^{\mathrm{a}}$ & $\mathrm{C}_{10} \mathrm{H}_{10} \mathrm{~N}_{2} \mathrm{O}$ \\
\hline 65 & $\begin{array}{l}\text { Anisole, p-1-cyclohexen- } \\
\text { 1-yl- }\end{array}$ & 1317.191 & 1560 & $55.95 \pm 0.03^{\mathrm{a}}$ & $4.99 \pm 0.01^{b}$ & & $\mathrm{C}_{13} \mathrm{H}_{16} \mathrm{O}$ \\
\hline 66 & trans-Nerolidol & 1318.886 & 1562 & & & $0.10 \pm 0.01^{\mathrm{a}}$ & $\mathrm{C}_{15} \mathrm{H}_{26} \mathrm{O}$ \\
\hline 67 & Bornyl tiglate & 1319.128 & 1615 & & $0.44 \pm 0.00^{\mathrm{a}}$ & & $\mathrm{C}_{15} \mathrm{H}_{24} \mathrm{O}_{2}$ \\
\hline 68 & Spathulenol & 1323.002 & 1571 & & $1.52 \pm 0.01^{\mathrm{a}}$ & & $\mathrm{C}_{15} \mathrm{H}_{24} \mathrm{O}$ \\
\hline 69 & Dendrasaline & 1324.697 & 1579 & $1.14 \pm 0.03^{\mathrm{a}}$ & & & $\mathrm{C}_{15} \mathrm{H}_{22} \mathrm{O}$ \\
\hline 70 & Benzoic acid, hexyl ester & 1329.297 & 1580 & & & $0.09 \pm 0.00^{\mathrm{a}}$ & $\mathrm{C}_{13} \mathrm{H}_{18} \mathrm{O}_{2}$ \\
\hline 71 & Caryophyllene oxide & 1334.382 & 1582 & & & $0.65 \pm 0.00^{\mathrm{a}}$ & $\mathrm{C}_{15} \mathrm{H}_{24} \mathrm{O}$ \\
\hline 72 & $\begin{array}{l}\text { Mintketone =Salvial-4(14)- } \\
\text { en-1-one }\end{array}$ & 1339.467 & 1599 & & $1.05 \pm 0.01^{\mathrm{a}}$ & & $\mathrm{C}_{15} \mathrm{H}_{24} \mathrm{O}$ \\
\hline 73 & $\begin{array}{l}\text { 9-Oxatetracy- } \\
\text { clo[5.4.0.0(3,10).0(4,8)] } \\
\text { undeca-5-en-2-one }\end{array}$ & 1347.215 & & & & $0.83 \pm 0.01^{\mathrm{a}}$ & $\mathrm{C}_{10} \mathrm{H}_{10} \mathrm{O}_{2}$ \\
\hline 74 & $\delta$-Cadinene & 1351.815 & 1537 & & $0.51 \pm 0.03^{\mathrm{a}}$ & & $\mathrm{C}_{15} \mathrm{H}_{24}$ \\
\hline 75 & $\begin{array}{l}\text { 2-methyl-2-vinyl-5-isopro- } \\
\text { pyltetrahydrofuran }\end{array}$ & 1353.510 & 1074 & & & $0.20 \pm 0.00^{\mathrm{a}}$ & $\mathrm{C}_{10} \mathrm{H}_{18} \mathrm{O}$ \\
\hline 76 & cis-Farnesol & 1356.416 & 1697 & & $2.79 \pm 0.00^{\mathrm{a}}$ & & $\mathrm{C}_{15} \mathrm{H}_{26} \mathrm{O}$ \\
\hline 77 & $\gamma$-Eudesmol & 1363.680 & 1630 & & $0.37 \pm 0.00^{b}$ & $0.47 \pm 0.02^{\mathrm{a}}$ & $\mathrm{C}_{15} \mathrm{H}_{26} \mathrm{O}$ \\
\hline 78 & Valencene & 1369.007 & 1496 & & $0.83 \pm 0.00^{\mathrm{a}}$ & & $\mathrm{C}_{15} \mathrm{H}_{24}$ \\
\hline 79 & Methyl jasmonate & 1370.944 & 1655 & & & $0.47 \pm 0.01^{\mathrm{a}}$ & $\mathrm{C}_{13} \mathrm{H}_{20} \mathrm{O}_{3}$ \\
\hline 80 & T-Cadinol & 1372.397 & 1639 & $0.81 \pm 0.00^{\mathrm{a}}$ & & & $\mathrm{C}_{15} \mathrm{H}_{26} \mathrm{O}$ \\
\hline 81 & 6-Hydroxy caryophyllene & 1376.513 & 1649 & $0.42 \pm 0.01^{\mathrm{a}}$ & & & $\underline{\mathrm{C}}_{15} \underline{\mathrm{H}}_{24} \mathrm{O}$ \\
\hline 82 & Neointermedeol & 1379.176 & 1662 & & $1.75 \pm 0.03^{\mathrm{a}}$ & & $\mathrm{C}_{15} \mathrm{H}_{26} \mathrm{O}$ \\
\hline
\end{tabular}


Table 2 (continued)

\begin{tabular}{|c|c|c|c|c|c|c|c|}
\hline No. & Component & RI Exp & RI Lit & $\begin{array}{l}\text { Tripleurospermum } \\
\text { disciforme } \\
\text { (C.A.Mey.) Sch.Bip }\end{array}$ & $\begin{array}{l}\text { Tanacetum } \\
\text { parthenium (L.) } \\
\text { Sch.Bip }\end{array}$ & $\begin{array}{l}\text { Achillea } \\
\text { biebersteinii } \\
\text { Afan }\end{array}$ & $\begin{array}{l}\text { Molecular } \\
\text { formula }\end{array}$ \\
\hline 83 & $\beta$-Eudesmol & 1378.934 & 1649 & & & $1.18 \pm 0.01^{\mathrm{a}}$ & $\mathrm{C}_{15} \mathrm{H}_{26} \mathrm{O}$ \\
\hline 84 & 2-Norcaranone, 3-methyl- & 1387.167 & 1657 & $0.54 \pm 0.00^{\mathrm{a}}$ & & & $\underline{\mathrm{C}}_{8} \underline{\mathrm{H}_{12}} \underline{\mathrm{O}}$ \\
\hline 85 & a-Bisabolol & 1391.283 & 1685 & & & $0.52 \pm 0.01^{\mathrm{a}}$ & $\mathrm{C}_{15} \overline{\mathrm{H}}_{26} \mathrm{O}$ \\
\hline 86 & $\begin{array}{l}\text { 4-(1,5-Dimethylhex-4-enyl) } \\
\text { cyclohex-2-enone }\end{array}$ & 1395.883 & 1697 & $1.54 \pm 0.01^{\mathrm{a}}$ & & & $\mathrm{C}_{14} \mathrm{H}_{22} \mathrm{O}$ \\
\hline 87 & $\begin{array}{l}\text { (1R,7S,E)-7-Isopropyl- } \\
\text { 4,10-dimethylenecyclo- } \\
\text { dec-5-enol }\end{array}$ & 1395.883 & 1694 & & $0.55 \pm 0.03^{\mathrm{a}}$ & & $\mathrm{C}_{15} \mathrm{H}_{24} \mathrm{O}$ \\
\hline 88 & $\gamma$-Costol & 1428.967 & 1745 & & & $0.08 \pm 0.02^{\mathrm{a}}$ & $\mathrm{C}_{15} \mathrm{H}_{24} \mathrm{O}$ \\
\hline 89 & Caparratriene & 1439.042 & 1692 & & $0.57 \pm 0.02^{\mathrm{a}}$ & & $\mathrm{C}_{15} \mathrm{H}_{26}$ \\
\hline 90 & 15-nor-Prezizaan-7-one & 1436.750 & 1572 & $0.34 \pm 0.04^{\mathrm{a}}$ & & & $\mathrm{C}_{14} \mathrm{H}_{22} \mathrm{O}$ \\
\hline 91 & Ascabiol & 1443.073 & 1753 & & & $0.16 \pm 0.00^{\mathrm{a}}$ & $\mathrm{C}_{14} \mathrm{H}_{12} \mathrm{O}_{2}$ \\
\hline 92 & $\begin{array}{l}\text { (4R,5S)-4-Methyl-5-phenyl- } \\
\text { 2-oxazolidinone }\end{array}$ & 1444.332 & 1754 & $0.83 \pm 0.03^{\mathrm{a}}$ & & & $\mathrm{C}_{10} \mathrm{H}_{11} \mathrm{NO}_{2}$ \\
\hline 93 & Farnesol & 1451.385 & 1747 & $0.28 \pm 0.02^{\mathrm{a}}$ & & & $\mathrm{C}_{15} \mathrm{H}_{26} \mathrm{O}$ \\
\hline 94 & $\begin{array}{l}\text { (Z)-8-decen-4,6-diyn-1-yl } \\
\text { 3-methylbutanoate }\end{array}$ & 1465.491 & 1832 & $0.73 \pm 0.01^{\mathrm{a}}$ & & & $\mathrm{C}_{15} \mathrm{H}_{20} \mathrm{O}_{2}$ \\
\hline 95 & $\begin{array}{l}\text { Phthalic acid, diisobutyl } \\
\text { ester }\end{array}$ & 1485.138 & 1868 & $0.16 \pm 0.05^{\mathrm{a}}$ & & & $\mathrm{C}_{16} \mathrm{H}_{22} \mathrm{O}_{4}$ \\
\hline 96 & (Z)-Tonghaosu & 1501.842 & 1891 & & $1.18 \pm 0.00^{\mathrm{a}}$ & & $\mathrm{C}_{13} \mathrm{H}_{12} \mathrm{O}_{2}$ \\
\hline 97 & Gerany-p-cymene & 1524.736 & 1980 & & & $0.29 \pm 0.01^{\mathrm{a}}$ & $\mathrm{C}_{20} \mathrm{H}_{30}$ \\
\hline 98 & 9-Octadecenal, (Z)- & 1544.210 & 1995 & & & $0.19 \pm 0.00^{\mathrm{a}}$ & $\mathrm{C}_{18} \mathrm{H}_{34} \mathrm{O}$ \\
\hline 99 & (E)-Tibetin spiroether & 1537.368 & 1888 & & $0.22 \pm 0.00^{\mathrm{a}}$ & & $\mathrm{C}_{14} \mathrm{H}_{14} \mathrm{O}_{2}$ \\
\hline 100 & Hexadecanoic acid & 1546.052 & 1959 & $0.75 \pm 0.02^{\mathrm{a}}$ & $0.63 \pm 0.02^{b}$ & & $\mathrm{C}_{16} \mathrm{H}_{32} \mathrm{O}_{2}$ \\
\hline 101 & cis-1-Chloro-9-octadecene & 1547.631 & 2241 & & & $0.11 \pm 0.03^{\mathrm{a}}$ & $\mathrm{C}_{18} \mathrm{H}_{35} \mathrm{Cl}$ \\
\hline 102 & 1,15-Hexadecadiene & 1580.000 & 1581 & & & $0.71 \pm 0.00^{\mathrm{a}}$ & $\mathrm{C}_{16} \mathrm{H}_{30}$ \\
\hline 104 & Behenic alcohol & 1590.263 & 2470 & & & $0.26 \pm 0.01^{\mathrm{a}}$ & $\mathrm{C}_{22} \mathrm{H}_{46} \mathrm{O}$ \\
\hline 105 & Z-9-Octadecen-1-ol acetate & 1635.734 & 1635 & & & $0.49 \pm 0.01^{\mathrm{a}}$ & $\mathrm{C}_{20} \mathrm{H}_{38} \mathrm{O}_{2}$ \\
\hline 106 & Octadecane & 1677.811 & 1789 & & & $0.08 \pm 0.03^{\mathrm{a}}$ & $\mathrm{C}_{18} \mathrm{H}_{38}$ \\
\hline 107 & Tricosane & 1686.980 & 2300 & & $0.54 \pm 0.01^{\mathrm{a}}$ & & $\mathrm{C}_{23} \mathrm{H}_{48}$ \\
\hline 108 & Linoleic acid & 1634.626 & 2134 & $0.53 \pm 0.02^{\mathrm{a}}$ & & & $\mathrm{C}_{18} \mathrm{H}_{32} \mathrm{O}_{2}$ \\
\hline \multirow[t]{7}{*}{109} & Phytan & 1688.919 & 1811 & $0.38 \pm 0.01^{\mathrm{a}}$ & & & $\mathrm{C}_{20} \mathrm{H}_{42}$ \\
\hline & \multicolumn{2}{|l|}{ Total } & & 98.78 & 99.55 & 99.94 & \\
\hline & \multicolumn{2}{|l|}{ Monoterpenes hydrocarbons } & & 0.00 & 16.2 & 27.91 & \\
\hline & \multicolumn{2}{|l|}{ Oxygenated monoterpenes } & & 0.15 & 47.21 & 51.76 & \\
\hline & \multicolumn{2}{|l|}{$\begin{array}{l}\text { Sesquiterpenes hydrocar- } \\
\text { bons }\end{array}$} & & 34.03 & 7.15 & 0.99 & \\
\hline & \multicolumn{2}{|l|}{ Oxygenated sesquiterpenes } & & 2.65 & 8.03 & 3 & \\
\hline & \multicolumn{2}{|l|}{ Others } & & 61.95 & 20.96 & 16.28 & \\
\hline
\end{tabular}

Compounds are listed in order of their retention time from a HP-5 column. RI Exp., linear retention indices on HP-5 column, experimentally determined using homologue series of $n$-alkanes (C8-C20). RI Lit., linear retention index taken from Adams [75], or NIST 14 (2014) and literature. Values with different letters are statistically different (Duncan, $P \leq 0.01$ ), mean $(\%) \pm S D$ of three cultures were reported

can isolate lipids from the cell wall of bacteria and fungi, thereby increasing cell membrane permeability. Disturbances in the function of the cell membrane lead to the release of ions and disturbance of the electron balance of the membrane, making the passage of substances difficult and ultimately leading to cell death. Several sources introduce terpenes and monoterpenes as effective factors in the antibacterial and antifungal activity of essential oils [102, 103].

In addition, due to the same antimicrobial properties of $A$. biebersteinii and $T$. parthenium essential oils, it can be inferred that different ratios of chemical compounds in different essential oils have balanced their antimicrobial activity $[90,104]$. In $A$. biebersteinii essential oil, 


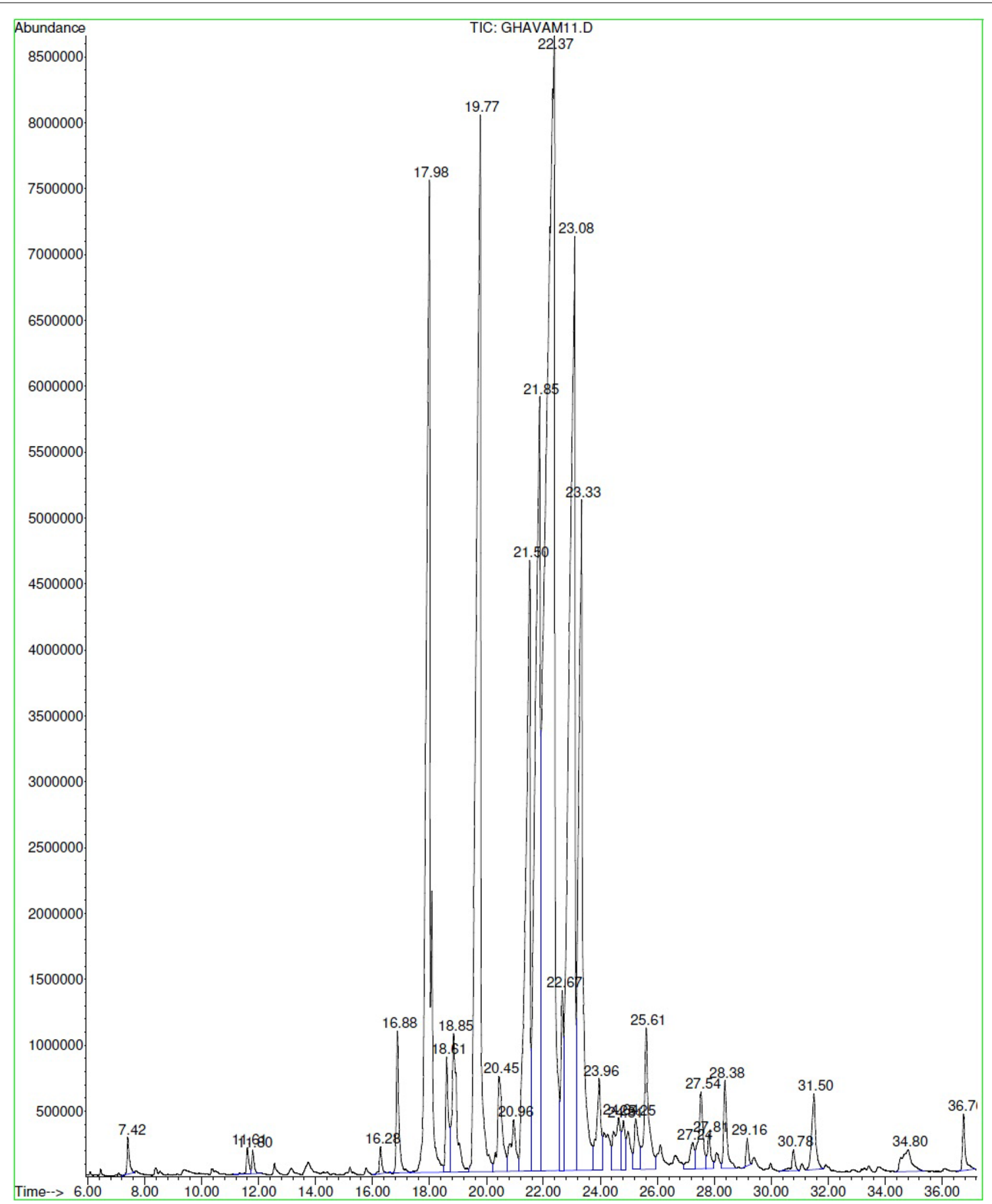

Fig. 1 Chemical profile of essential oil of Tripleurospermum disciforme (C.A.Mey.) Sch.Bip.

the predominance of $p$-cymene, linalool, $\alpha$-terpineol, terpinen-4-ol, and linalool acetate and in T. parthenium essential oil, the predominance of camphene, camphor, and bornyl acetate can be the most effective factors on this activity of essential oils. Many studies have confirmed the antimicrobial activity of these compounds against different strains [56, 105-110].
Findings of Tofighi et al. [20] proved that T. disciforme essential oil was not inactive against E. coli, which is consistent with the present results. Differences in the antimicrobial activities of the essential oil of a plant species in different regions can be due to 


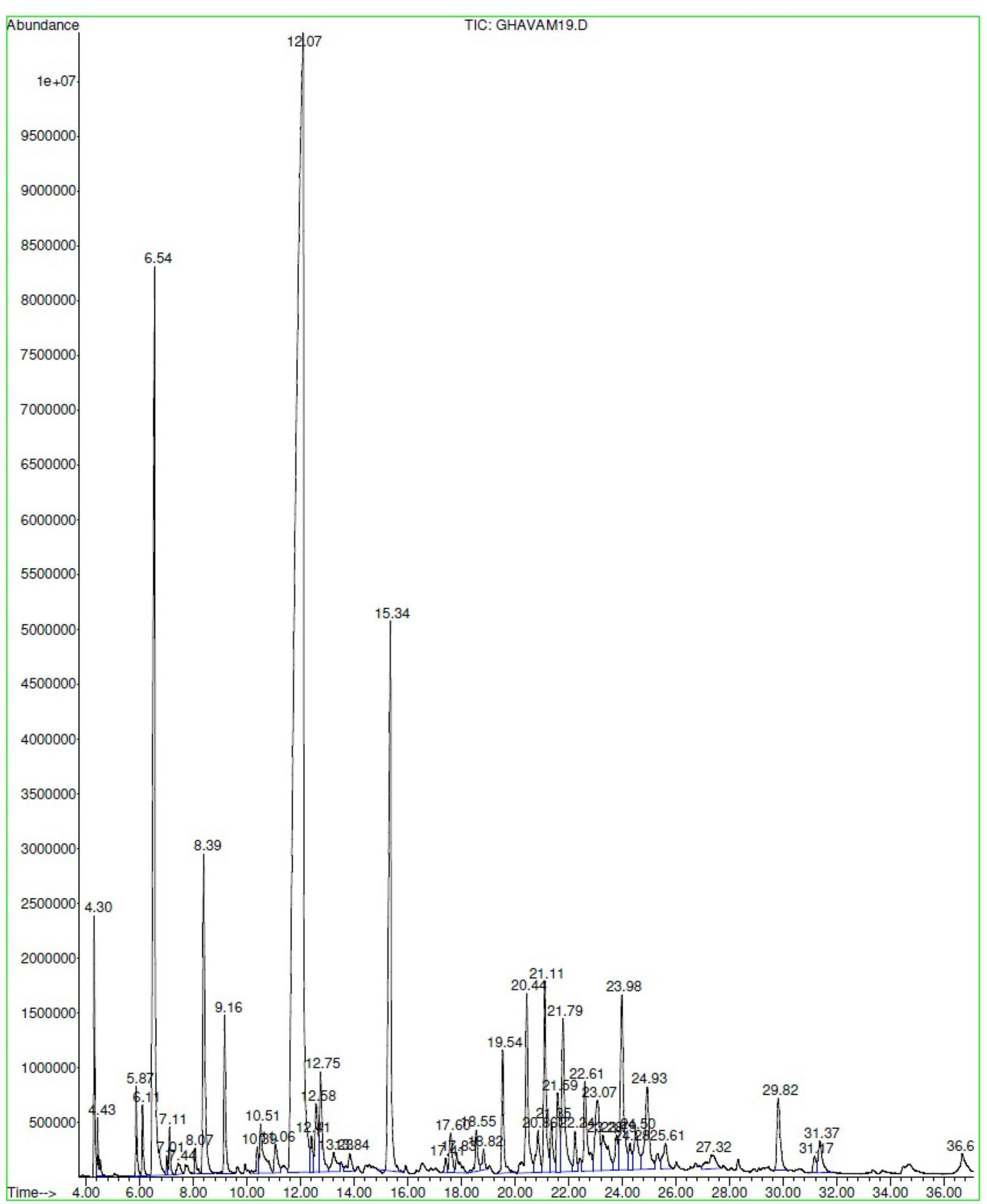

Fig. 2 Chemical profile of essential oil of Tanacetum parthenium (L.) Sch.Bip.

differences in its predominant compounds or the presence of different chemical compounds in it [111].

The predominance of modephene, cis- $\beta$-farnesene, $\beta$-sesquiphellandrene, and anisole, $p$-1-cyclohexen$1-y l$ in $T$. disciforme essential oil can be the cause of strong antibacterial activity. On the other hand, the antimicrobial activity of essential oils does not depend only on their predominant compounds, and minor compounds may have a synergistic effect with other compounds. Enough attention must be given to these synergistic effects due to the diversity between the main and minor compounds of essential oils in 


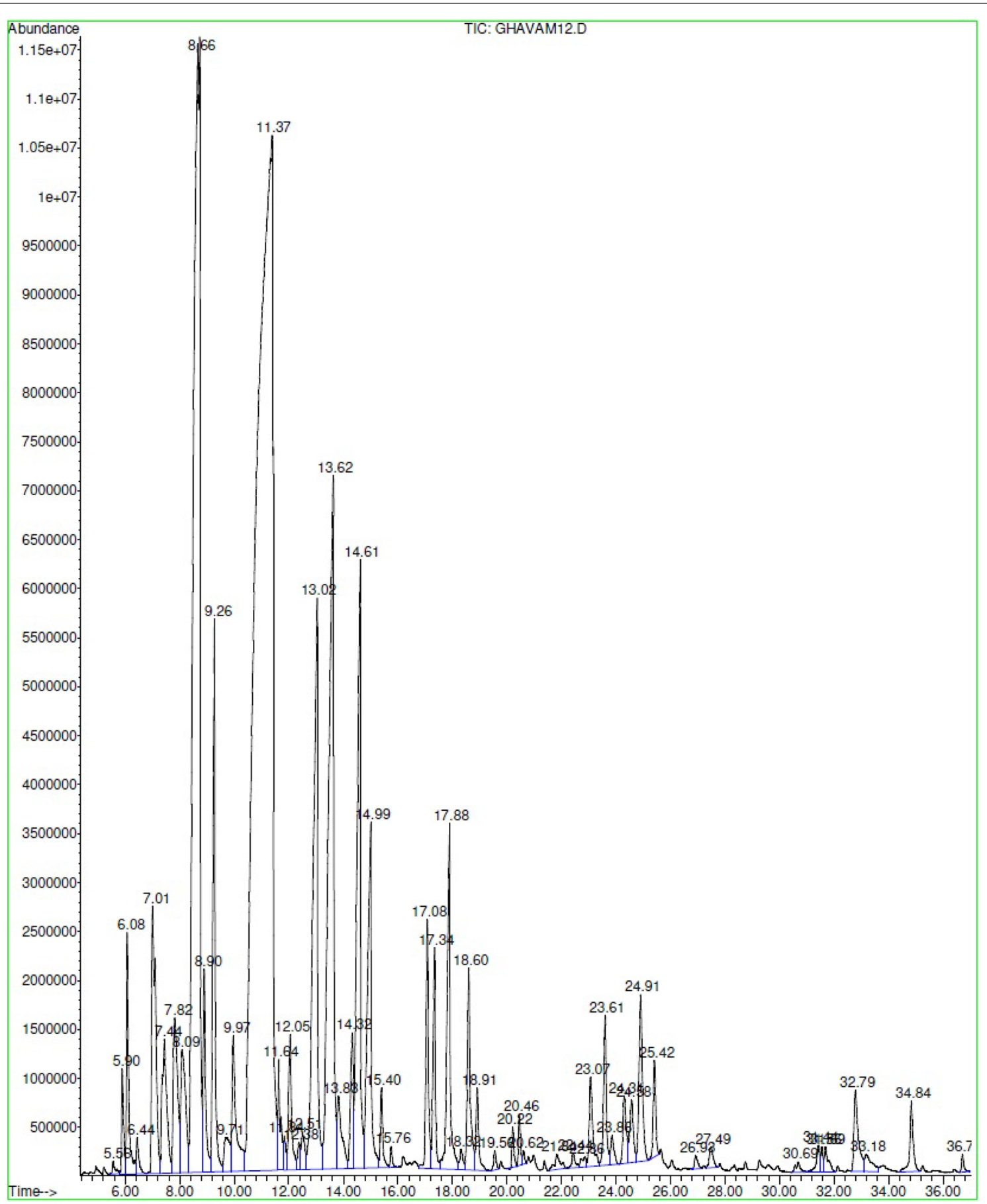

Fig. 3 Chemical profile of essential oil of Achillea biebersteinii Afan

their antimicrobial activity [89-91, 112, 113]. Therefore, a higher amount of caryophyllene compared to the other two essential oils and also the small and exclusive presence of some sesquiterpene such as $\alpha$-guaiene, $\alpha$-amorphene, $\beta$-bisabolene, $\tau$-cadinol, and farnesol, can be other possible factors affecting this antibacterial activity. The effect of sesquiterpene on different strains of bacteria has been documented [114]. The presence of low fatty acid linoleic acid can also be another factor since the antibacterial effect of fatty acids against $E$. coli has been proven [115]. 
Table 3 ANOVA of the effect of species on inhibition zone of essential oil of oils of Tripleurospermum disciforme (C.A.Mey.) Sch.Bip., Tanacetum parthenium (L.) Sch.Bip. and Achillea biebersteinii Afan. for some tested strains

\begin{tabular}{|c|c|c|c|c|c|c|c|}
\hline \multirow{2}{*}{$\begin{array}{l}\text { Source of } \\
\text { variation }\end{array}$} & \multirow[t]{2}{*}{$d f$} & \multicolumn{6}{|l|}{ MS } \\
\hline & & A. brasiliensis & B. subtilis & C. albicans & $\begin{array}{l}\text { K. pneumoniae/E. } \\
\text { coli }\end{array}$ & Sh. dysenteriae & S. aureus \\
\hline Species & 2 & $1.444^{\mathrm{ns}}$ & $16.083^{* *}$ & $18.778^{* *}$ & $6.250^{* *}$ & $5.444^{* *}$ & $20.250^{* *}$ \\
\hline Error & 6 & 0.444 & 0.472 & 0.111 & 0.083 & 0.11 & 0.083 \\
\hline
\end{tabular}

ns not significant

** $1 \%$ level of probability is significant

Table 4 WD (mm) of essential oils of Tripleurospermum disciforme (C.A.Mey.) Sch.Bip., Tanacetum parthenium (L.) Sch.Bip. and Achillea biebersteinii Afan. against tested strains

\begin{tabular}{|c|c|c|c|c|c|c|}
\hline \multirow[t]{3}{*}{ Strains } & \multicolumn{6}{|l|}{ WD (mm) } \\
\hline & \multicolumn{3}{|l|}{ Essential oils } & \multicolumn{3}{|c|}{ Antibiotics } \\
\hline & $\begin{array}{l}\text { Tripleurospermum disciforme } \\
\text { (C.A.Mey.) Sch.Bip }\end{array}$ & $\begin{array}{l}\text { Tanacetum parthenium } \\
\text { (L.) Sch.Bip }\end{array}$ & $\begin{array}{l}\text { Achillea } \\
\text { biebersteinii Afan }\end{array}$ & Rifampin & Gentamicin & Nystatin \\
\hline A. brasiliensis & $12.00 \pm 0.50^{b}$ & $13.00 \pm 0.50^{\mathrm{a}}$ & $13.00 \pm 0.50^{\mathrm{a}}$ & NA & NA & 30 \\
\hline A. sniger & ND & ND & ND & NA & NA & 27 \\
\hline C. albicans & $10.33 \pm 0.58^{\mathrm{a}}$ & ND & ND & NA & NA & 33 \\
\hline B. subtilis & $9.17 \pm 0.29^{b}$ & $13.00 \pm 0.50^{\mathrm{a}}$ & $13.00 \pm 0.50^{\mathrm{a}}$ & 19 & 30 & NA \\
\hline E. coli & $8.50 \pm 0.50^{\mathrm{a}}$ & ND & ND & 11 & 20 & NA \\
\hline K.pneumoniae & $8.50 \pm 0.50^{\mathrm{a}}$ & ND & ND & 8 & 17 & NA \\
\hline P. aeruginosa & ND & ND & ND & ND & 20 & NA \\
\hline S. paratyphi-A & ND & ND & ND & 8 & 18 & NA \\
\hline Sh. dysenteriae & $8.33 \pm 0.58^{a}$ & ND & ND & 9 & 17 & NA \\
\hline S. aureus & ND & $10.50 \pm 0.50^{\mathrm{a}}$ & ND & 21 & 27 & NA \\
\hline S. epidermidis & ND & ND & ND & 27 & 45 & NA \\
\hline S.pyogenes & ND & ND & ND & 21 & 32 & NA \\
\hline
\end{tabular}

Values with different letters are statistically different (Duncan, $P \leq 0.01$ ); Mean (\%) $\pm S D$ of three cultures were reported

WDThe diameters of the inhibition zones includes the diameters of wells $(6 \mathrm{~mm}), N D$ not determined, NA no activity

Anti-yeast activity may be due to the presence of farnesol in $T$. disciforme essential oil compared to other essential oils studied. Sesquiterpenols have 15 carbon atoms and have a variety of therapeutic effects and activity against Candida [116]. Tofighi et al. [20] did not establish the diameter of the inhibition zone of $T$. disciforme essential oil against $P$. aeruginosa. Similarly, the findings indicate that the MIC and $\mathrm{MBC}$ values of $T$. disciforme essential oil against S. pyogenes were $<62.50 \mu \mathrm{g} / \mathrm{mL}$. Although it was 6 times weaker compared with rifampin and gentamicin $(0.975 \mu \mathrm{g} / \mathrm{mL})$, it had a good performance compared to the essential oils of the other two species (MIC and $\mathrm{MBC}=2000 \mu \mathrm{g} / \mathrm{mL}$ ).

Studies have shown that the essential oil as a whole has stronger antiseptic effects than each of its main components [117]. It has also been shown that many compounds in essential oils (even in small amounts) have good antimicrobial effects and even synergistic effects on other compounds [118]. Camphor too has strong antimicrobial effects [119]. The pure antimicrobial properties of $\alpha$-pinene against $S$. aureus have been proven [120]. $\beta$-Pinene has antibiotic properties against Escherichia and Staphylococcus bacteria [89, $121,122]$. Spathulenol is an alcoholic sesquiterpene with proven antibacterial and antifungal properties [123].

\section{Conclusion}

The present study showed that the essential oils of different species were significantly different in terms of yield, chemical properties and antimicrobial properties. The compounds of anisole, $p$-1-cyclohexane-1-yl-, camphor and linalool were the predominant and significant amounts in the essential oils of three plants, $T$. disciforme, T. parthenium and A. biebersteinii, respectively. 
Table 5 MIC values of essential oils of Tripleurospermum disciforme (C.A.Mey.) Sch.Bip., Tanacetum parthenium (L.) Sch.Bip. and Achillea biebersteinii Afan. against tested strains

\begin{tabular}{|c|c|c|c|c|c|c|}
\hline \multirow[t]{3}{*}{ Strains } & \multicolumn{6}{|l|}{ MIC } \\
\hline & \multicolumn{3}{|l|}{ Essential oils } & \multicolumn{3}{|c|}{ Antibiotics } \\
\hline & $\begin{array}{l}\text { Tripleurospermum } \\
\text { disciforme (C.A.Mey.) } \\
\text { Sch.Bip }\end{array}$ & $\begin{array}{l}\text { Tanacetum } \\
\text { parthenium (L.) Sch. } \\
\text { Bip }\end{array}$ & $\begin{array}{l}\text { Achillea biebersteinii } \\
\text { Afan }\end{array}$ & Rifampin & Gentamicin & Nystatin \\
\hline A. brasiliensis & 2000 & 2000 & 2000 & NA & NA & 31.2 \\
\hline A. niger & 2000 & 2000 & 2000 & NA & NA & 31.2 \\
\hline C. albicans & $>62.50$ & 2000 & 2000 & NA & NA & 125 \\
\hline B. subtilis & 125 & 2000 & 2000 & 31.25 & 3.90 & NA \\
\hline E. coli & 125 & 2000 & 2000 & 3.90 & 3.90 & NA \\
\hline K.pneumoniae & 125 & 2000 & 2000 & 15.36 & 3.90 & NA \\
\hline$P$. aeruginosa & $>62.50$ & 2000 & 2000 & 31.25 & 7.81 & NA \\
\hline S. paratyphi-A & 125 & 2000 & 2000 & 15.36 & 3.90 & NA \\
\hline Sh. dysenteriae & 125 & 2000 & 2000 & 15.36 & 3.90 & NA \\
\hline S. aureus & 250 & 2000 & 2000 & 31.25 & 1.95 & NA \\
\hline S. epidermidis & 125 & 2000 & 2000 & 1.95 & 1.95 & NA \\
\hline S.pyogenes & $>62.50$ & 2000 & 2000 & 0.975 & 0.975 & NA \\
\hline
\end{tabular}

Table 6 MFC/MBC values of essential oils of Tripleurospermum disciforme (C.A.Mey.) Sch.Bip., Tanacetum parthenium (L.) Sch.Bip. and Achillea biebersteinii Afan. against tested strains

\begin{tabular}{|c|c|c|c|}
\hline \multirow[t]{3}{*}{ Strains } & \multicolumn{3}{|l|}{ MBC } \\
\hline & \multicolumn{3}{|l|}{ Essential oils } \\
\hline & $\begin{array}{l}\text { Tripleurospermum } \\
\text { disciforme } \\
\text { (C.A.Mey.) Sch.Bip }\end{array}$ & $\begin{array}{l}\text { Tanacetum } \\
\text { parthenium (L.) } \\
\text { Sch.Bip }\end{array}$ & $\begin{array}{l}\text { Achillea } \\
\text { biebersteinii } \\
\text { Afan }\end{array}$ \\
\hline A. brasiliensis & 2000 & 2000 & 2000 \\
\hline A. niger & 2000 & 2000 & 2000 \\
\hline C.albicans & $>62.50$ & 2000 & 2000 \\
\hline B. subtilis & 1000 & 4000 & 2000 \\
\hline E. coli & 250 & 2000 & 2000 \\
\hline $\begin{array}{l}\text { K. pneumo- } \\
\text { niae }\end{array}$ & 250 & 2000 & 2000 \\
\hline P. aeruginosa & 250 & 2000 & 2000 \\
\hline S. paratyphi-A & 250 & 2000 & 2000 \\
\hline Sh. dysenteriae & 250 & 2000 & 2000 \\
\hline S. aureus & 2000 & 4000 & 4000 \\
\hline S. epidermidis & 125 & 2000 & 2000 \\
\hline S.pyogenes & $>62.50$ & 2000 & 2000 \\
\hline
\end{tabular}

Differences in the predominant and partial compositions of essential oils were caused different antimicrobial properties against different strains of microorganisms. The highest inhibition zone by essential oil of T. parthenium and $A$. biebersteinii against $A$. brasiliensis was observed. The strongest inhibitory and lethal effect was against $K$. pneumoniae, Sh. Dysenteriae, E. coli, and C. albicans by the essential oil of $T$. disciforme. These essential oils can be a natural candidate for the treatment of some infectious diseases, but further clinical studies should be performed in the future.

\section{Acknowledgements}

Not applicable.

Authors' contributions

MG was the supervisor, designer of the hypotheses, and responsible and functor for all the steps (plant collection, laboratory, statistical analysis, data analysis, etc.) and wrote the text of the article. The author read and approved the final manuscript.

\section{Funding}

No funding.

Availability of data and materials

Not applicable.

\section{Declarations}

Ethics approval and consent to participate

Not applicable.

Consent for publication

Not applicable.

\section{Competing interests}

The authors declare no competing interests.

Received: 8 May 2021 Accepted: 23 July 2021

Published online: 15 September 2021

\section{References}

1. Weli A, Al-Omar W, Al-Sabahi J, Gilani S, Alam T, Philip A, Hossain M, Touby S. Biomarker profiling of essential oil and its antibacterial and 
cytotoxic activities of Cleome austroarabica. Adv Biomark Sci Technol. 2021;3:1-7.

2. Ceylan S, Cetin S, Camadan Y, Saral O, Tutus A. Antibacterial and antioxidant activities of traditional medicinal plants from the Erzurum region of turkey. Ir J Med Sci. 2019;188:1303-9.

3. Rolain JM, Abat C, Jimeno MT, Fournier PE, Raoult D. Do we need new antibiotics? Clin Microb Infect Dis. 2016;22:408-15.

4. Okeke IN, et al. Antimicrobial resistance in developing countries. Part I: recent trends and current status. Lancet Infect Dis. 2005:5:481-93.

5. Silveira ZS, Macêdo NS, Freitas TS, Silva ARP, Santos JFSM, Braga MFB, Costa JGM, Teixeira RNP, Kamdem JP, Coutinho HDM, Cunha FAB. Antibacterial enhancement of antibiotic activity by Enterolobium contortisiliquum (Vell.) Morong. Asian Pac J Trop Med. 2017;7:945-9.

6. Calixto-Júnior JT, Morais SM, Martins CG, Vieira LG, Morais-Braga MFB, Carneiro JN, Machado AJP, Menezes IRA, Tintino SR, Coutinho HDM. Phytochemical analysis and modulation of antibiotic activity by Luehea paniculata Mart. \& Zucc. (Malvaceae) in multiresistant clinical isolates of Candida spp. Comput Biomed Res. 2015;2015:1-10.

7. Ribeiro RV, Bieski IGC, Balogun SO, Martins DTO. Ethnobotanical study of medicinal plants used by Ribeirinhos in the North Araguaia microregion, MatoGrosso, Brazil. J Ethnopharmacol. 2017;205:69-102.

8. Salehi P, Sonboli A, Eftekhar F, Nejadebrahimi S, Yousefzadi M. Essential oil composition antibacterial and antioxidant activity of the oil and various extracts of Ziziphora clinopodioides subsp. rigida from Iran. Biol Pharm Bull. 2005;28:1892-6.

9. Edris AE. Pharmaceutical and therapeutic potentials of essential oils and their individual volatile constituents: a review. Phytother Res. 2007;21:308-23.

10. Napoli E, Ruberto G, Siracusa L. New tricks for old guys: recent developments in the chemistry, biochemistry, applicationsand exploitations of selected species from Lamiaceae family. Chem Biodivers. 2020;17:e1900677.

11. Sharmeen JB, Shanoo S, Kannan RRR, Fawzi MM. Chemistry, bioactivities, mode of action and industrial application ofessential oils. Trend Food Sci Technol. 2020;101:89-105.

12. Mahmodi R, Tajik H, Farshid AA, Ehsani A, Zaree P, Moradi M. Phytochemical properties of Mentha longifolia L. essential oil and its antimicrobial effects on Staphylococcus aureus. Armaghane Danesh. 2011;16:400-12.

13. Bremer K. Asteraceae, cladistics and classification. Portland:Timber Press, Inc; 1994. p. 752.

14. Funk VA, Susanna A, Stuessy T, Bayer R. Systematic, evolution and biogeography of the compositae. Vienna: International Association for Plant Taxonomy; 2009.

15. Polatoglu K, Demirci F, Demirci B, Gören N, Baser KC. Antibacterial activity and the variation of Tanacetum parthenium (L.) Schultz Bip. Essential oils from Turkey. J Oleo Sci. 2010;59:177-84.

16. Arabasi D, Bayram E. The effect of nitrogen fertilization and different plant densities on some agronomic and technologic characteristic of (Tanacetum parthenium L). J Essent Oil Res. 2005;7:203-5.

17. Ghassemi-Dehkordi N, Amin G, Rahiminejad R, Salehi M, Jafarpisheh A. Morphological and phytochemical study of Tripleurospermum disciforme (C.A. Mey) Schultz Bip. Pajouhesh Sazandegi. 2003:58:42-6.

18. Nadaf M, Joharchi MR, Amiri MS. Ethnomedicinal uses of plants for the treatment of nervous disorders at the herbal markets of Bojnord, North Khorasan Province, Iran. Avicenna J Phytomed. 2019;9:153-63.

19. Herrero O, Peropadre A, Freire PF, Martin JMP, Peña E, Hazen MJ. Bis(2-ethylhexyl) phthalate: much more than a peroxisome proliferator. Toxicol Lett. 2007;172:S46-7.

20. Tofighi Z, Molazem M, Doostdar B, Taban P, Shahverdi AR, Samadi N, Yassa N. Antimicrobial activities of three medicinal plants and investigation of flavonoids of Tripleurospermum disciforme. Iran J Pharm Res. 2015;14:225-31.

21. Bakhtiarian A, Ejtemaimehr S, Strobl S, Pournaghash-Tehrani S, Partoazar A, Ghamami G, Yasa N. Inhibition of carrageenan-induced edemaby tripleurospermum disciforme extract in rats. Pak J Biol Sci. 2007;10:2237-40

22. Hosseini M, Parvini S, Bakhtiarian A. Antiinflammatory, analgesic activity of Tripleurospermum disciforme extract in rats. Toxicol Lett. 2007; 172:47-47
23. Minaiyan M, Ghassemi-Dehkordi N, Mohammadzadeh B. Antiulcer effect of Tripleurospermum disciforme (C.A. Mey) Schultz-Bip. On pylorus ligated rats. Res Pharm Sci. 2006;1:15-21.

24. Grainger B, Wichtl M. Herbal drugs and phytopharmaceuticals. Stuttgart: Medpharm Scientific Publishers; 2006

25. MH SS, Yasa N, Aynechi Y, Emami M, Shidfar M, Amin M, Moghadami M, Kordbacheh P, Zeini F. Screening of Iranian plants for antifungal activity: part 1. DARU J Pharma Sci. 2002;10:34-7.

26. Amin G, Dehmoobed-Sharifabadi A, Salehi Surmaghi MS, Yasa N, Ayenechi Y. Screening of Iranian plants for antifungal activity. Daru. 2004;10:38-48.

27. Chehregani A, Mohsenzadeh F, Mirazi N, Hajisadeghian S, Baghali Z. Chemical composition and antibacterial activity of essential oils of Tripleurospermum disciforme in three developmental stages. Pharm Biol. 2010;11:1280-4.

28. Souri E, Sarkhail P, Kaymanesh P, Amini M, Farsam H. Antioxidant activity of extract and a new isolated dioxaspiran derivative of Tripleurospermum disciforme. Pharm Biol. 2005:43:620-3.

29. Cavar Zeljkovic S, Ayaz FA, Inceer H, Hayirlioglu-Ayaz S, Colak N. Evaluation of chemical profile and antioxidant activity of Tripleurospermum insularum, a new species from Turkey. Nat Prod Res. 2015;29:293-6.

30. Javidnia K, Miri R, Soltani M, Khosravi AR. Essential oil com-position of Tripleurospermum disciforme from Iran. Chem Nat Compd. 2008;44:800-1.

31. Jaimand K, Rezaee MB. Investigation extraction by two differentapparatus and effects of essential oils on content and constituents of Tripleuro-spermum disciforme (C.A.Mey) Schultz-Bip. Pajouhesh-vaSazandegi. In Nat Sci. 2003;60:2-7.

32. Yasar A, Ucuncu O, Gulec C, Inceer H, Ayaz S. Essential oil composition of Tripleurospermum disciforme from Iran. Pharm Biol. 2005;43:108-12.

33. Alipoor N, Sefidkon F. Quantitative and qualitative study of the essential oil from aromatic and medicinal Tripleurospermum disciforme (C.A. Mey) Schultz-Bip. J Med Plant. 2004:4:33-41.

34. Özturk E, Özer H, Çakir A, Mete E, Kandemir A, Polat T. Chemical composition of the essential oil of Tripleurospermum corymbosum E. Hossain, an Endemic Species from Turkey. J Essent Oil Bear Plants. 2010;13(2):148-53.

35. Dermarderosian A. A guid to popular natural products. Facts \& comparisons. St. Louis: Wolters Kluwer Company; 2001. p. 90-2.

36. Zargary A. Plant medicine. 6th ed. Tehran: Tehran University Press; 1997.

37. Benassi-Zanqueta É, Marques CF, Valone LM, Pellegrini BL, Bauermeister A, Ferreira ICP, Lopes NP, Nakamura CV, Dias Filho BP, Natali MRM, UedaNakamura T. Evaluation of anti-HSV-1 activity and toxicity of hydroethanolic extract of Tanacetum parthenium (L.) Sch. Bip. (Asteraceae). Phytomedicine. 2019;55:249-54

38. Ernestt $\mathrm{E}$, Pittler MH. The efficacy and safety of feverfew (Tanacetum parthenium): an update of a systemic review. Public Health Nutr. 2000;3:509-14.

39. Park SJ, Shin HJ, Youn HS. Parthenolide inhibits TRIF-dependent signaling pathway of Toll-like receptors in RAW264.7 macrophages. Mol Cells. 2011;31:261-5.

40. Williams C, Harborne JB, Geiger H, Robin J, Hoult S. The flavonoids of Tanacetum parthenium and T. vulgare and their anti-inflammatory properties. Phytochemistry. 1999;51:417-23.

41. Ghantous A, Sinjab A, Herceg Z, Darwiche N. Parthenolide: from plant shoots to cancer roots. Drug Discov Today. 2013;18:894-905.

42. Habibi Z, Yousefi M, Shahriari F, Khalafi J, As'habibi MA. Chemical composition of the essential oil of Tanacetum turcomanicum and $T$. canescens from Iran. Chem Nat Comp. 2009;45:3-95.

43. Mohsenzadeh AC, Amiri H. Chemical composition, antibacterial activity and cytotoxicity of essential oils of Tanacetum parthenium in different developmental stages. Pharm Biol. 2011:49:920-6.

44. Saharkhiz M, Sattari M, Goodarzi G, Omidbaigi R. Assessment of antibacterial properties of Tanacetum parthenium L. essential oil. Iran J Med Aromat Plants Res. 2008;24:47-55.

45. Izadi Z, Modarres Sanavi S, Sorooshzadeh A, Esna-Ashari M, Davoodi P. Antimicrobial activity of chamomile (Matricaria chamomilla L.) and feverfew (Tanacetum parthenium L.). Armaghane Danesh. 2013;18:31-43.

46. Maxia A, Sanna C, Piras A, Porcedda S, Danilo F, Gonçalves M, Cavaleiro C, Salgueiro L. Chemical composition and biological activity of 
Tanacetum audibertii (Req.) DC. (Asteraceae), an endemic species of Sardinia Island, Italy. Ind Crops Prod. 2015;65:472-6.

47. Hethelyi E, Tetenyi P, Danos B, Koczka I. Phytochemical and antimicrobial studies on the essential oils of the Tanacetum vulgare clones by gas chromatography/mass spectrometry. Herba Hung. 1991;30:82-90.

48. Onozato T, Nakamura CV, Cortez DA, Dias Filho BP, Ueda-Nakamura T. Tanacetum vulgare: antiherpes virus activity of crude extract and the purified compound parthenolide. Phytother Res. 2009;23:791-6.

49. Hough-Golstein J, Hahn SP. Antifeedant and oviposition deterrent activity of an aqueous extract of Tanacetum vulgare $\mathrm{L}$. on two cabbage pest. Environ Entomol. 1992;21:837-44.

50. Bernath J. Medicinal and aromatic plants. Budapest: Mezo Publication; 2000. p. 667p.

51. Rezaei F, Jamei R, Heidari R. Evaluation of the phytochemical and antioxidant potential of aerial parts of Iranian Tanacetum parthenium. Pharm Sci. 2017;23:136-42.

52. Mojab F, Tabatabai SA, Naghdi-Badi H, Nickavar B, Ghadyani F. Essential oil of the root of Tanacetum parthenium (L.) Schultz. Bip. (Asteraceae) from Iran. Iran J Pharm Res. 2007;6:291-3.

53. Akpulat HA, Tepe B, Sokmen A, Daferera D, Polissiou M. Composition of the essential oils of Tanacetum argyrophyllum (C. Koch) Tvzel. var. argyrophyllum and Tanacetum parthenium (L.) Schultz Bip. (Asteraceae) from Turkey. Biochem Syst Ecol. 2005;33:511-6.

54. Hendriks H, Bos R, Woerdenbag J. The essential oil of Tanacetum parthenium (L.) Schultz-Bip. Flavour Fragr J. 1996;11:367-71.

55. Salamci E, Kordali S, Kotan R, Cakir A, Kaya Y. Chemical compositions, antimicrobial and herbicidal effects of essential oils isolated from Turkish Tanacetum aucheranum and Tanacetum chiliophyllum var. chiliophyllum. Biochem Syst Ecol. 2007;35:569-81.

56. Awang DV. Prescribing therapeutic feverfew (Tanacetum parthenium (L.) Schultz Bip., syn. Chrysanthemum parthenium (L.) (Bernh.). Integr Med. 1998:5:11-3.

57. Long C, Sauleau P, David B, Lavaud C, Cassabois V, Ausseil F, Massiot G. Bioactive flavonoids of Tanacetum parthenium revisited. Phytochem. 2003:64:567-9.

58. Saeidnia S, Gohari AR, Mokhber-Dezfuli N, Kiuchi F. A Review on phytochemistry and medicinal properties of the genus Achillea. DARU J Pharm Sci. 2011;19:173-86.

59. Alkofahi A, Batshoun R, Qwais W, Najib N. Biological activity of some Jordanian medicinal plant extracts. Fitoterapia. 1996;57:435-42.

60. Baytop TT, Bitki Adlarõ S.zl. ÛA. Dictionary of vernacular names of wild, T.rk Dil Kurumlarõ Yayõnlarõ. Ankara. 1997:578:163-238.

61. Sezik E, Yeßilada E, Honda G. Traditional medicine in Turkey X. Folk medicine in Central Anatolia. J Ethnopharmacol. 2001;75:95-115.

62. Bader A, Flamini G, Cioni PL, Morelli I. Essential oil composition of Achillea santolina $\mathrm{L}$. and Achillea biebersteinii Afan. collected in Jordan. Flavour Fragr J. 2003;18:36-8.

63. Kordali S, Aslan I, Calmasur O, Cakir A. Toxicity of essential oils isolated from three Artemisia species and some of their major components to granary weevil, Sitophilus granarius (L.) (Coleoptera: Curculionidae). Ind Crop Prod. 2006;23:162-70.

64. Bariş Ö, Gulluce M, Şahin F, Özer H, Kiliç H, Ozkan H. Biological activities of the essential oil and methanol extract of Achillea biebersteinii Afan. (Asteraceae). Turk J Biol. 2006;30:65-73.

65. Sokmen A, Sokmen M, Daferera D. The in vitro antioxidant and antimicrobial activities of the essential oil and methanol extracts of Achillea biebersteini Afan. (Asteraceae). Phytother Res. 2004;18:451-6.

66. Rezaei F, Jamei R. Phytochemical and antioxidant activity of essential oil in root of Achillea millefolium, Achillea biebersteinii in natural regions of Gilan province. Eco-phytochem J Med Plants. 2018;5:44-54.

67. Mirahmadi S, Hasandokht M, Sefidkon F, Hassani M. A comparative study on chemical constituents of essential oils from different populations of Achillea biebersteinii Afan. growing wild in khorasan using multivariate statistical analyses. Iran J Med Aromat Plants Res. 2012;28:1-13.

68. Tabanca N, Demirci B, Gurbuz I, Demirci F, Becnel JJ, Wedge DE, Baser KHC. Essential oil composition of five collections of Achillea biebersteinii from central Turkey and their antifungal and insecticidal activity. Nat Prod Commun. 2011;6:701-6.

69. Polatoğlu K, Karakoç ÖC, Gören N. Phytotoxic, DPPH scavenging, insecticidal activities and essential oil composition of Achillea vermicularis, $A$. teretifolia and proposed chemotypes of A. biebersteinii (Asteraceae). Ind Crop Prod. 2013;51:35-45.

70. Elshafie Kordali S, Cakir A, Aytaş Akçin T, Mete E, Akcin A, Aydin T, Kilic $H$. Antifungal and herbicidal properties of essential oils and $n$-hexane extracts of Achillea gypsicola Hub-Mor. and Achillea biebersteinii Afan. (Asteraceae). Ind Crops Prod. 2009;29:562-70.

71. Rahimmalek M, Tabatabaei BES, Etemadi N, Goli SAH, Arzani A, Zeinali H. Essential oil variation among and within six Achillea species transferred from different ecological regions in Iran to the field conditions. Ind Crop Prod. 2009;29:348-55.

72. Esmaeili A, Nematollahi F, Rustaiyan A, Moazami N, Masoudi S, Bamaisan S. Volatile constituents of Achillea pachycephala, A. oxyodonta and A. bieber-steinii from Iran. Flavour Fragr J. 2006;21:253-6.

73. Vaez Shahrestani A, Sefidkon F. Essential oil composition in different plant parts of Achillea biebersteinii Afam. Iran J Med Aromat Plants Res. 2018;34:40-9.

74. Kaffash S, Sefidkon F, Mafakheri S. Comparing essential oil composition of cultivated and wild samples of Achillea biebersteinii Afan. in Kurdistan Province. J Med Plants By-product. 2020;9:149-58.

75. Adams RP. Identification of essential oil components by gas chromatography/quadruple mass spectroscopy. Carol Stream: Allured Publishing Corporation; 2007.

76. CLSI (Clinical and Laboratory Standard Institute). Performance standards for antimicrobial disk susceptibility testing: approved standard, vol. 29. National Committee for Clinical Laboratory Standards; 2012. p. 1-76.

77. Gul HI, Ojanen T, Hänninen O. Antifungal evaluation of bis Mannich bases derived from acetophenones and their corresponding piperidinols and stability studies. Bio Pharm Bull. 2002;25:1307-10.

78. Nazar Alipoor A, Sefidkon F. Quantitative and qualitative study of the essential oil from aromatic and medicinal Tripleurospermum disciforme (C.A.Mey.) Schultz-Bip. J Med Plants. 2003;2:33-40.

79. Golkar P, Mosavat N, Jalali SAH. Essential oils, chemical constituents, antioxidant, antibacterial and in vitro cytotoxic activity of different Thymus species and Zataria multiflora collected from Iran. S Afr J Bot. 2020. https://doi.org/10.1016/j.sajb.2019.12.005.

80. Silva VP, Alves CC, Miranda ML, Bretanha LC, Balleste MP, Micke G, Silveira E, Martins C, Ambrosio MA, Silva TS, Tavares D, Magalhães L, Silva FG, Egea MB. Chemical composition and in vitro leishmanicidal, antibacterial and cytotoxic activities of essential oils of the Myrtaceae family occurring in the Cerrado biome. Ind Crops Prod. 2018;123:638-45.

81. Ngahang Kamte SL, Ranjbarian F, Cianfaglione K, Sut S, Dall'Acqua S, Bruno M, Afshar FH, lannarelli R, Benelli G, Cappellacci L, Hofer A, Maggi F, Petrelli R. Identification of highly effective antitrypanosomal compounds in essential oils from the Apiaceae family. Ecotoxicol Environ Saf. 2018;30:154-65.

82. Tundis R, Nadjafi F, Menichini F. Angiotensin- converting enzyme inhibitory activity and antioxidant properties of Nepeta crassifolia Boiss. \& Buhse and Nepeta binaludensis Jamzad. Phytother Res. 2013;27:572-80.

83. Alizadeh M, Yaryab S, Jafari A, Salehi P. Variation of morphological traits, shoot yield, essential oil yield and growing degree-days in the populations of psedu chamomile (Tripleurospermum sevasnense (Manden.) Pobed.). Iran J Med Aromat Plants Res. 2016;31:967-76.

84. Golparvar AR, Ghasemi Pirbalouti A. Genetic improvement of essence percent and dry flower yield using indirect selection in German chamomile (Matricaria Chamomilla L.). J Herb Drugs. 2011;1:33-40.

85. Shakeri H, Ghasemi-Varnamkhasti M, Maleki A, Ghasemi A, Hosseinzadehsamani B. Effects of different drying methods on the quality and quantity of the essential oil of feverfew (Tanacetum Parthenium L.). Iran J Biosyst Eng. 2017:48:172-165.

86. Shafaghat A, Ghorban-Dadras O, Mohammadhosseini M, Akhavan M, Shafaghatlonbar M, Panahi A. A comparative study on chemical composition and antimicrobial activity of essential oils from Tanacetum parthenium (L.) Schultz. Bip. and Tanacetum punctatum (Desr.) Grierson. Leaves from Iran. J Essent Oil Bear Plants. 2017;20:1143-50.

87. Zuzarte M, Salgueiro L. Essential oils chemistry. In: de Sousa D, editor. Bioactive essential oils and cancer. Berlin: Springer; 2015. p. 19-61.

88. Yavari AR, Nazeri V, Sefidkon F, Hassani ME. Evaluation of some ecological factors, morphological traits and EOproductivity of Thymus migricus Klokov \& Desj.-Shost. Iran J Med Aromat Plants. 2010;26:227-38. 
89. Ghavam M, Afzali A, Manca ML. Chemotype of damask rose with oleic acid (9 octadecenoic acid) and its antimicrobial effectiveness. Sci Rep. 2021;11:8027

90. Ghavam M, Afzali A, Manconi M, Bachetta G, Manca ML. Variability in chemical composition and antimicrobial activity of essential oil of Rosa $\times$ damascena Herrm. from mountainous regions of Iran. Chem Biol Technol Agric. 2021:8:22.

91. Ghavam M, Manconi M, Manco ML, Bachetta G. Extraction of essential oil from Dracocephalum kotschyi Boiss. (Lamiaceae), identification of two active compounds and evaluation of the antimicrobial properties. J Ethnopharmacol. 2021;267:1-26.

92. Ghavam M, Manca ML, Manconi M, Bachetta G. Chemical composition and antimicrobial activity of essential oils obtained from leaves and flowers of Salvia hydrangea DC. ex Benth. Sci Rep. 2020;10:15647.

93. Chen N, Sun G, Yuan X, Hou J, Wu Q, Soromou LW, Feng H. Inhibition of lung inflammatory responses by bornyl acetate is correlated with regulation of myeloperoxidase activity. J Surg Res. 2014;186:436-45.

94. Alizadeh Behbahani B, Fooladi AAl. Antibacterial activities, phytochemical analysis and chemical composition Makhlaseh extracts against the growth of some pathogenic strain causing poisoning and infection. Microb Pathog. 2018;114:204-8.

95. Aali E, Mahmoudi R, Kazeminia M, Hazrati R, Azarpey F. Essential oils as natural medicinal substances: review article. Tehran Univ Med J. 2017:7:480-9.

96. Eikani MH, Golmohammad F, Rowshanzamir S. Subcritical water extraction of essential oils from coriander seeds (Coriandrum sativum L.). J Food Eng. 2007:80:735-40

97. Mirahmadi SF, Norouzi R. Chemical composition, phenolic content, free radical scavenging and antifungal activities of Achillea biebersteinii. Food Biosci. 2017;18:53-9. https://doi.org/10.1016/j.fbio.2017.04.004

98. Sartorelli P, Marquioreto AD, Amaral-Baroli A, Lim MEL, Moreno PRH. Chemical compositionand antimicrobial activity of the essential oils from two species of Eucalyptus. Phythother Res. 2007;21:231-3.

99. Elshafie HS, Ghanney N, Mang SM, Ferchichi A, Camele I. An in vitro attempt for controlling severe phytopathogens and human pathogens using essential oils from mediterranean plants of genus Schinus. J Med Food. 2016:19(3):266-73.

100. Popović-Djordjević J, Cengiz M, Ozer MS, Sarikurkcu C. Calamintha incana: essential oil composition and biological activity. Ind Crop Prod. 2019;128:162-6.

101. Pichersky E. Biosynthesis of plant volatiles: nature's diversity and ingenuity. Science. 2006;311:808-11.

102. Ultee A, Bennink MHJ, Moezelaar R. The phenolic hydroxyl group of carvacrol is essential foraction against the food-borne pathogen Bacillus cereus. Appl Environ Microbiol. 2002;68:1561-8.

103. Moazeni M, Saharkhiz MJ, Hosseini AA. In vitro lethal effect of ajowan (Trachyspermum ammi L.) essential oil on hydatid cyst protoscolices. Vet Parasitol. 2012;187:203-8.

104. Ghavam M. Relationships of irrigation water and soil physical and chemical characteristics with yield, chemical composition and antimicrobial activity of Damask rose essential oil. PLOS ONE. 2021;16(4):e0249363.

105. Napoli E, Di Vito M. Toward a new future for essential oils. Antibiotics. 2021;10:207.

106. Khajehie N, Golmakani M, Eblaghi M, Eskandari M. Investigating the effect of microwaves on chemical composition and antioxidant and antifungal activities of Salvia mirzayanii essential oil. Res Innov Food Sci Technol. 2017:6:157-70

107. Loughlin R, Gilmore B, McCarron P, Tunney M. Comparison of the cidal activity of tea tree oil and terpinen-4-ol against clinical bacterial skin isolates and human fibroblast cells. Lett Appl Microbiol. 2008:46:428-33.
108. Yamamoto N, Fujiwara S, Saito-Lizumi K, Kamei A, Shinozaki F, et al. Effects of inhaled (S)- linalool on hypothalamic gene expression in rats under restraint stress. Biosci Biotechnol Biochem. 2013;77:2413-8.

109. Marilena C, Bersani C, Comi G. Impedance measurements to study the antimicrobial activity of essential oils from Lamiaceae and Compositae. Int J Food Microbiol. 2001;67:187-95.

110. Juliano C, Mattana A, Usai M. Composition and in vitro antimicrobial activity of the essential oilof Thymusherba-barona Loisel growing wild in Sardinia. J Essent Oil Res. 2000;12:516-22.

111. Walia S, Mukhiac S, Bhatte V, Kumara R, Kumara R. Variability in chemical composition and antimicrobial activity of Tagetes minuta L. essential oil collected from different locations of Himalaya. Ind Crop Prod. 2020;150:112449.

112. Raut JS, Karuppayil SM. Bioprospecting of plant essential oils for medicinal uses. In: Fulekar M, Pathak B, Kale R, editors. Environment and sustainable development. New Delhi: Springer; 2014. p. 59-76.

113. Raut JS, Karuppayil SM. A status review on the medicinal properties of essential oils. Ind Crops Prod. 2014:62:250-64.

114. Ishnava K, Chauhan J, Barad M. Anticariogenic and phytochemical evaluation of Eucalyptus globulus. Saudi J Biol Sci. 2013;20(1):69-74.

115. Tajik H, Shokouhi Sabet Djalali F. In vitro assessment of antibacterial properties of fatty acids and their monoglycerids derivatives against Escherichia coli O157:H7. Iran J Med Microbiol. 2011;4:51-8.

116. Cordeiro R, Teixerira C, Brilhante R, Casteol-Branco D, Paiva M. Minimum inhibitory con-centrations of amphotericin B, azoles and caspofungin against Candida species are reduced by farnesol. Med Mycol. 2013;51:53-9.

117. Gill AO, Delaquis P, Russo P, Holley RA. Evaluation of antilisterial action of cilantro oil onvacuum packed ham. Int J Food Microbiol. 2002;73:83-92.

118. Burt S. Essential oils: their antibacterial properties and potential applications in foods - a review. Int J Food Microbiol. 2004;94:223-53.

119. Majdjabari T, Rustaiyan A, Vatan puor H. Study the ingredients of in essential oil. Tanacetum khorassanicum (Krasch.) Parsa. J Med Plants. 2003;6:15-20

120. Gilsic S, Milojeij S, Dimitrjvi J, Orlovij A, Skala D. Antimicrobial activity of the $\mathrm{EO}$ and different fractions of Juniperus communis $\mathrm{L}$. and a comparison with some commercial antibiotics. J Serb Chem Soc. 2007:4:311-20.

121. Dhar P, Chan DT, Khawam F, Gibbons S, Snyder-Leiby TE, Dickstein PK, Rai G. Watal synthesis, antimicrobial evaluation, and structure activity relationship of a-pinene derivatives. J Agric Food Chem. 2014;62:3548-52.

122. Mohammadi N, Ghasemi A, Aghabarari B, Hamehi B. Essential oil mixtures, anti-bacterial and antioxidant activity of essential oil of Nigella sativa L. different ecotypes in different habitats Iran. Eco-phyto Chem J Med Plants. 2016:4:58-68.

123. Taherkhani M, Masoudi Sh, Fatah Elahi R, Baradari T, Rustayian A. Identify the compounds in the essential oils of two plants from the Apiaceae family, Reichenb Torilis leptophylla and Boiss Thecocarpus meifolius, and study their antibacterial properties. Iran J Chem Chem Engine. 2012;31:70-65.

\section{Publisher's Note}

Springer Nature remains neutral with regard to jurisdictional claims in published maps and institutional affiliations. 